

\title{
BUKU AJAR MATA KULIAH PENGEMBANGAN PEMBELAJARAN IPS SD
}

\author{
Oleh \\ Vanda Rezania, S.Psi., M.Pd \\ Rifki Afandi, S.E., M.Pd
}

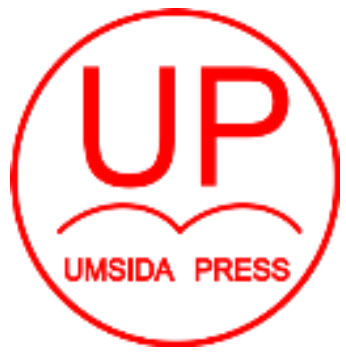

Diterbitkan oleh UMSIDA PRESS 


\section{BUKU AJAR \\ PENGEMBANGAN PEMBELAJARAN IPS SD}

\section{Penulis:}

Vanda Rezania, S.Psi., M.Pd

Rifki Afandi, S.E., M.Pd

\section{ISBN :}

978-623-6833-99-5

\section{Editor:}

Mohammad Faizal Amir, M.Pd

Design Sampul dan Tata Letak:

Mochammad Nashrullah, S.Pd

Yoga Ammy Prajati, S.Kom

Penerbit:

UMSIDA Press

Anggota IKAPI No. 218/Anggota Luar Biasa/JTI/2019

Anggota APPTI No. 0020181092017

Redaksi

Universitas Muhammadiyah Sidoarjo

Jl. Mojopahit No 666B

Sidoarjo, Jawa Timur

Cetakan Pertama, September 2020

CHak Cipta dilindungi undang undang

Dilarang memperbanyak karya tulis ini dengan sengaja, tanpa ijin tertulis dari penerbit. 


\section{KATA PENGANTAR}

Segala puji dan syukur, penulis panjatkan kepada Allah SWT yang Maha Pengasih dan Maha Penyayang, yang telah mencurahkan segala nikmat, rahmat, dan hidayahNya kepada penulis sehingga buku kami yang kedua dengan judul Pengembangan Pembelajaran IPS SD dapat diselesaikan dengan baik. Sholawat dan salam semoga senantiasa dilimpahkan oleh Allah SWT atas junjungan dan teladan seluruh insan Rasulullah SAW.

Tim penulis mengucapkan terima kasih kepada:

1. Dr. AKhtim Wahyuni, M.Ag., Dekan Fakultas Psikologi dan Ilmu Pendidikan yang memberikan arahan dan motivasi kepada penulis dalam menyelesaikan buku ajar ini.

2. Tri Linggo Wati, M.Pd., Kaprodi Pendidikan Guru Sekolah Dasar yang telah memberikan dukungan untuk menyusun buku ajar ini

3. Rekan-rekan dosen pengampu mata kuliah Pengembangan Pembelajaran IPS SD yang telah berbagi pengalaman dalam mengampu mata kuliah tersebut.

Penulis menyadari bahwa buku ini masih belum sempuna. Sebagai suatu karya awal, disadari benar akan segala keterbatasan dan kekurangan buku ini baik struktur maupun isinya. oleh karena itu, segala kritik dan saran dari para pembaca sangat dinantikan untuk penyempurnaan di masa mendatang. 


\section{DAFTAR ISI}

\section{HALAMAN SAMPUL}

KATA PENGANTAR

\section{DAFTAR ISI}

BAB I. MAKNA PENGEMBANGAN PEMBELAJARAN IPS SD 1

a. Urgensi Pengembangan Pembelajaran IPS 1

b. Karakteristik Mata Pelajaran IPS di SD 9

c. Dimensi Pembelajaran IPS SD 15

BAB II. PEMBELAJARAN IPS MENGgunAKAN METOdE 22 SIMULASI

a. Hakikat dan Pengertian Metode Simulasi 22

b. Tujuan Metode Simulasi 24

c. Kelebihan dan Kekurangan Metode Simulasi 25

d. Implementasi Metode Simulasi dalam Pembelajaran IPS 27

BAB III. PENDEKATAN PEMBELAJARAN KONSTRUKTIVISME 31

a. Pengertian Konstruktivisme 31

b. Ciri-ciri Pembelajaran Konstruktivisme 33

c. Implementasi Pendekatan Konstruktivisme 34

d. Metode Mengajar dalam Pendekatan Konstruktivisme 37

BAB IV. PENDEKATAN INKUIRI DALAM PEMBELAJARAN ILMU 43 PENGETAHUAN SOSIAL

a. Pengertian Pendekatan Pembelajaran Inkuiri 43

b. Ciri-ciri Pendekatan Pembelajaran Inkuiri 45

c. Implementasi Pendekatan Inkuiri dalam 47

Pembelajaran IPS 
BAB V.PENGGUNAAN MODEL PEMBELAJARAN KOOPERATIF 56 DALAM PENDIDIKAN IPS

a. Pengertian Model Pembelajaran Kooperatif 56

b. Ciri-ciri Model Pembelajaran Kooperatif 58

c. Implementasi Model Pembelajaran Kooperatif 60

d. Teknik Model Pembelajaran Kooperatif 63

BAB VI. PENDEKATAN SAINS TEKNOLOGI DAN MASYARAKAT 68 DALAM PENGEMBANGAN PEMBELAJARAN IPS SD

a. Pengertian Pendekatan Sains Teknologi dan Masyarakat 68

b.Tujuan Pendekatan Sains Teknologi dan Masyarakat 70

c. Karakteristik Pendekatan Sains Teknologi dan Masyarakat 71

d. Ciri-ciri Pendekatan Sains Teknologi dan Masyarakat 72

e. Penerapan Pendekatan Sains Teknologi dan Masyarakat $\quad 75$

BAB VII. PEMANFAATAN MEDIA DALAM PEMBELAJARAN IPS 82

a. Pengertian Media Pembelajaran 82

b. Fungsi dan Kegunaan Media Pembelajaran 84

c. Karakteristik Media Pembelajaran $\quad 89$

d. Jenis-jenis Media Pembelajaran 89

BAB VIII. RANCANGAN PEMBELAJARAN 93

a. Desain Pembelajaran 93

$\begin{array}{ll}\text { b. RPP } 1 \text { Halaman } & 97\end{array}$

$\begin{array}{ll}\text { DAFTAR PUSTAKA } & 101\end{array}$

BIODATA PENULIS 


\section{BATANG TUBUH DAN SUB-CAPAIAN PEMBELAJARAN MATA KULIAH}

\begin{tabular}{|c|c|}
\hline BAB & Sub-Capaian Pembelajaran Mata Kuliah \\
\hline $\begin{array}{l}\text { BAB I } \\
\text { MAKNA } \\
\text { PENGEMBANGAN } \\
\text { PEMBELAJARAN } \\
\text { IPS SD }\end{array}$ & $\begin{array}{l}\text { 1. Mahasiswa mampu memahami urgensi } \\
\text { pengembangan pembelajaran IPS SD } \\
\text { 2. Mahasiswa mampu memahami karakteristik mata } \\
\text { pelajaran IPS SD } \\
\text { 3. Mahasiswa mampu memahami dimensi } \\
\text { pembelajaran IPS }\end{array}$ \\
\hline $\begin{array}{l}\text { BAB II } \\
\text { PEMBELAJARAN } \\
\text { IPS } \\
\text { MENGGUNAKAN } \\
\text { METODE SIMULASI }\end{array}$ & $\begin{array}{l}\text { 1. Mahasiswa mampu memahami hakikat metode } \\
\text { simulasi } \\
\text { 2. Mahasiswa mampu memahami pengertian metode } \\
\text { simulasi } \\
\text { 3. Mahasiswa mampu memahami tujuan metode } \\
\text { simulasi } \\
\text { 4. Mahasiswa mampu memahami kelebihan dan } \\
\text { kekurangan metode simulasi } \\
\text { 5. Mahasiswa mampu memahami implementasi } \\
\text { metode simualsi dalam pembelajaran IPS }\end{array}$ \\
\hline $\begin{array}{l}\text { BAB III } \\
\text { PENDEKATAN } \\
\text { PEMBELAJARAN } \\
\text { KONSTRUKTIVISME }\end{array}$ & $\begin{array}{l}\text { 1. Mahasiswa mampu memahami pengertian } \\
\text { konstruktivisme } \\
\text { 2. Mahasiswa mampu memahami ciri-ciri } \\
\text { pembelajaran konstruktivisme } \\
\text { 3. Mahasiswa mampu memahami implementasi } \\
\text { pendekatan konstruktivisme } \\
\text { 4. Mahasiswa mampu mensimulasikan metode } \\
\text { mengajar dalam pendekatan konstruktivisme }\end{array}$ \\
\hline $\begin{array}{l}\text { BAB IV } \\
\text { PENDEKATAN } \\
\text { INKUIRI DALAM } \\
\text { PEMBELAJARAN } \\
\text { ILMU } \\
\text { PENGETAHUAN } \\
\text { SOSIAL }\end{array}$ & $\begin{array}{l}\text { 1. Mahasiswa mampu memahami pengertian } \\
\text { pendekatan pembelajaran inkuiri } \\
\text { 2. Mahasiswa mampu memahami ciri-ciri pendekatan } \\
\text { pembelajaran inkuiri } \\
\text { 3. Mahasiswa mampu mensimulasikan pendekatan } \\
\text { inkuiri dalam pembelajaran IPS }\end{array}$ \\
\hline
\end{tabular}




\begin{tabular}{|c|c|}
\hline $\begin{array}{l}\text { BAB V } \\
\text { PENGGUNAAN } \\
\text { MODEL } \\
\text { PEMBELAJARAN } \\
\text { KOOPERATIF } \\
\text { DALAM } \\
\text { PENDIDIKAN IPS }\end{array}$ & $\begin{array}{l}\text { 1. mahasiswa mampu memahami pengertian model } \\
\text { pembelajaran kooperatif } \\
\text { 2. mahasiswa mampu memahami ciri-ciri model } \\
\text { pembelajaran kooperatif } \\
\text { 3. mahasiswa mampu mensimulasikan implementasi } \\
\text { pembelajaran kooperatif dan teknik-tekniknya }\end{array}$ \\
\hline $\begin{array}{l}\text { BAB VI } \\
\text { PENDEKATAN } \\
\text { SAINS TEKNOLOGI } \\
\text { DAN MASYARAKAT } \\
\text { DALAM } \\
\text { PENGEMBANGAN } \\
\text { PEMBELAJARAN } \\
\text { IPS SD }\end{array}$ & $\begin{array}{l}\text { 1. mahasiswa mampu memahami pengertian } \\
\text { pendekatan sains teknologi dan masyarakat } \\
\text { 2. mahasiswa mampu memahami tujuan pendekatan } \\
\text { sains teknologi dan masyarakat } \\
\text { 3. mahasiswa mampu memahami karakteristik dan } \\
\text { ciri-ciri pendekatan sains teknologi dan masyarakat } \\
\text { 4. mahasiswa mampu mensimulasikan pendekatan } \\
\text { sains teknologi dan masyarakat }\end{array}$ \\
\hline $\begin{array}{l}\text { BAB VII } \\
\text { PEMANFAATAN } \\
\text { MEDIA DALAM } \\
\text { PEMBELAJARAN } \\
\text { IPS }\end{array}$ & $\begin{array}{l}\text { 1. Mahasiswa mampu memahami pengertian media } \\
\text { pembelajaran } \\
\text { 2. Mahasiswa mampu memahami fungsi dan kegunaan } \\
\text { media pembelajaran } \\
\text { 3. Mahasiswa mampu memahami karakteristik media } \\
\text { pembelajaran } \\
\text { 4. Mahasiswa mampu memahami jenis-jenis media } \\
\text { pembelajaran }\end{array}$ \\
\hline $\begin{array}{l}\text { BAB VIII } \\
\text { RANCANGAN } \\
\text { PEMBELAJARAN }\end{array}$ & $\begin{array}{l}\text { 1. Mahasiswa mampu menyusun silabus pembelajaran } \\
\text { 2. Mahasiswa mampu menyusun RPP } \\
\text { 3. Mahasiswa mampu menyusun RPP } 1 \text { lembar }\end{array}$ \\
\hline
\end{tabular}


BAB I

MAKNA PENGEMBANGAN PEMBELAJARAN IPS SD

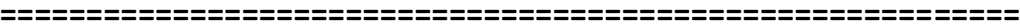
TUJUAN PEMBELAJARAN

- Mahasiswa mampu memahami urgensi kebutuhan pembelajaran IPS SD

- Mahasiswa mampu menyebutkan karakteristik pembelajaran IPS SD

- Mahasiswa mampu mensintesis dimensi pembelajaran IPS SD

\section{a. Urgensi Pembelajaran IPS SD}

Belajar adalah suatu proses perubahan dalam membentuk dan mengarahkan kepribadian manusia. Perubahan tersebut ditempatkan dalam bentuk peningkatan kualitas dan kuantitas seseorang.

Belajar berhubungan dengan perubahan tingkah laku seseorang terhadap situasi yang disebabkan oleh pengalamannya yang berulang-ulang dalam situasi itu, dimana perubahan tingkah laku itu dapat dijelaskan atas dasar kecenderungan respons pembawaan kematangan. Proses belajar peserta didik akan terjadi apabila terdapat 
suatu situasi beriringan dengan ingatan sebelumnya sehingga perilaku yang ditunjukkan akan berangsurangsur berubah dari perilaku (perfomasce) awal.

Contoh dalam kehidupan sehari-hari adalah kegiatan belajar yang berdampak pada hasil belajar peserta didik. Apakah hasil belajar itu? Hasil belajar adalah hasil akhir dari perubahan perilaku yang terdiri dari pemahaman/pengetahuan/kognitif, sikap, dan keterampilan yang didapat dari selama proses pembelajaran. Hasil belajar merupakan hal terpenting selama proses pembelajaran. Dengan mengetahui hasil belajar, maka guru dapat mengetahui informasi terkait kemajuan peserta didik dalam usahanya mencapai tujuan pembelajaran. Selama proses pembelajaran, mereka menggunakan semua kemampuan/kompetensi yang dimiliki. Kompetensi tersebut antara lain: pengetahuan/kognitif, sikap, dan keterampilanketerampilan.

Melihat penjelasan terkait hasil belajar diatas, dapat diambil kesimpulan bahwa pembelajaran IPS tentu saja memiliki tujuan yang mulia, yaitu mengajak peserta didik untuk dapat memahami beberapa hak dan kewajiban mereka sebagai anggota masyarakat dan warga negara. Peserta didik dapat memahami dan mengembangkan nilai-nilai, pengetahuan, keterampilan sosial, fakta-fakta, konsep-konsep sosial serta menerapkan di lingkungan masyarakat. Tentu saja, pembelajaran IPS merupakan bekal hidup mereka setelah dewasa. Apabila guru mampu menerapkan dan meneladani pada peserta didiknya akan dapat menjadikan peserta didik sebagai manusia yang 
"Paripurna", dalam arti manusia yang memiliki jiwa sosial yang tinggi yang memiliki kepedulian yang tinggi kepada manusia lainnya. Lebih lanjut, Mariani (2007: 6) menjelaskan bahwa tujuan pembelajaran IPS adalah untuk: 1) Mengembangkan pengetahuan dasar ilmu-ilmu sosial; 2) Mengembangkan kemampuan berpikir inkuiri, pemecahan masalah dan keterampilan sosial: 3) Membangun komitmen dan kesadaran terhadap nilai-nilai kemanusiaan; dan 4) meningkatkan kemampuan berkompetensi dan bekerjasama dalam masyarakat yang majemuk baik dalam skala nasional maupun skala internasional.

Proses pembelajaran pendidikan IPS di jenjang persekolahan, baik pada tingkat pendidikan dasar maupun menengah, perlu adanya pembaharuan yang serius, karena pada kenyataannya selama ini masih banyak model pembelajaran yang masih bersifat konvensional tidak terlihat adanya improvisasi dalam pembelajaran, jauh dari model pembelajaran yang modern sesuai dengan tuntutan zaman dan kondisi lingkungan sekitar di mana peserta didik berada titik salah satu contoh model atau pendekatan pembelajaran yang modern tersebut adalah model pembelajaran kontekstual. Model pembelajaran kontekstual tersebut dianggap sebagai upaya pembaharuan dalam pembelajaran pendidikan IPS. Pembaharuan pembelajaran pendidikan IPS tersebut ditandai oleh beberapa ciri seperti yang dikemukakan oleh Somantri (2001: 2), yaitu: 1) menyesuaikan bahan pembelajaran dengan minat dan kebutuhan peserta didik; 2) bahan pelajaran lebih melibatkan contoh-contoh 
permasalahan sosial di lingkungan terdekat; 3) Bahan pelajaran berisi kegiatan yang meminta peserta didik untuk melakukan penyelidikan sehingga keterampilan inkuirinya meningkat; dan 4) bahan pelajaran berisi tentang ajakan atau menanam kepekaan peserta didik untuk menjaga kelestarian lingkungan sekitar. Oleh karena itu itu, para pengajar hendaknya berupaya mewujudkan proses pembelajaran IPS yang aktif, inovatif, kreatif, efektif, dan menyenangkan (PAIKEM), sesuai dengan ciri-ciri pembaharuan pembelajaran IPS yang berorientasi pada pembelajaran kontekstual tersebut. Dalam pakai PAIKEM tidak hanya guru yang aktif Tetapi lebih ditekankan adalah bagaimana supaya peserta didik lebih aktif dan kreatif dalam belajar sehingga suasana belajar menjadi lebih kondusif dan menyenangkan. Hal ini akan mudah tercapai dengan pemilihan metode pembelajaran serta strategi pembelajaran yang tepat. Namun hal tersebut masih dikatakan belum sempurna atau belum menjamin, karena pemilihan metode dan strategi pembelajaran lama-kelamaan akan menimbulkan kebosanan pada peserta didik. Untuk itu selain penggunaan metode yang tepat perlu adanya penggunaan media yang tepat pula untuk menarik perhatian peserta didik.

Namun kenyataan yang ada sampai saat ini masih banyak guru yang masih menerapkan model pembelajaran konvensional, khususnya dalam pembelajaran IPS. Masih terdapat kelemahan dalam pelaksanaan proses pembelajaran pendidikan IPS, sekalipun berbagai inovasi telah dilakukan pembelajaran 
konvensional ini diantaranya, guru kurang lebih cenderung menggunakan ceramah yang hanya menuntut peserta didik pada kekuatan ingatan dan hafalan kejadiankejadian serta nama-nama tokoh, tanpa mengembangkan wawasan berpikir dan penyelesaian masalah yang memungkinkan peserta didik dapat belajar lebih aktif.

Secara terperinci, Somantri

(2001:39)

mengemukakan beberapa hal yang berkaitan dengan permasalahan tersebut diatas, yaitu:

1. Pendekatan ekspositori sangat menguasai keseluruhan proses belajar mengajar titik kalaupun ada diskusi tetapi tidak ada hubungannya dengan prosedur berpikir ilmu sosial;

2. Hirarki belajar hampir tidak ditemui baik dalam penyusunan satuan pelajaran, proses belajar, konstruksi tes, maupun dalam buku pelajaran;

3. Tingkat pengetahuan sebagian besar peserta didik berada dalam kelompok peringkat 1 (fakta) dan eringkat 2 (konsep). Adapun generalisasi sebagai peringkat 3 hampir tidak digunakan;

4. penyebaran kawasan tujuan instruksional tidak memungkinkan peserta didik belajar aktif; dan

5. Mata pelajaran sejarah dan ilmu sosial lainnya sangat membosankan dan kurang membantu dalam permulaan di perguruan tinggi maupun manfaatnya bagi kehidupan masyarakat.

Kelemahan lainnya, yang menjadikan kualitas pembelajaran pendidikan IPS dianggap remeh dan kurang berkualitas adalah adanya pandangan yang salah atau keliru dari para orang tua (yang bisa diturunkan ke 
peserta didiknya), serta para pengambil keputusan yang menganggap bahwa pembelajaran IPS itu kurang berkualitas layaknya mata pelajaran IPA. IPS dianggap kurang dapat memberikan nilai-nilai manfaat dalam kehidupan sehari-hari. Hal tersebut merupakan pandangan yang salah. IPS merupakan pembelajaran yang mengajak peserta didik untuk memiliki kepekaan sosial serta melakukan kewajiban-kewajiban sebagai anggota masyarakat yang bak dan bertanggung jawab.

Contoh lain, pembelajaran IPS dianggap tidak mampu untuk mengaplikasikan nilai-nilai manfaat dan hanya memiliki kepentingan sesaat tanpa ada manfaat yang besar dalam kehidupan bermasyarakat. Sehingga IPS selalu dianggap remeh. Banyak penelitian oleh mahapeserta didik yang selalu menggunakan mata pelajaran IPS sebagai objek penelitiannya. Hampir semua hasil observasi awal mengatakan bahwa pembelajaran IPS di kelas selalu kurang maksimal karena terlalu banyak hafal, media pembelajaran yang terbatas, dan minat peserta didik yang rendah.

Suwarna (2004: 53) mengidentifikasi beberapa kelemahan guru pendidikan IPS ke dalam tujuh hal serius, yaitu:

1. Pendidikan IPS tidak bertindak sebagai fasilitator akan tetapi lebih banyak bertindak dan berposisi sebagai sumber belajar;

2. Guru pendidikan IPS lebih banyak cenderung tampil sebagai pendidik yang dapat mengembangkan secara terintegrasi dimensi intelektual emosional dan sosial; 
3. Pendidikan IPS lebih cenderung bertindak sebagai pemberi bahan pembelajaran belum bertindak pembelajar;

4. Pendidikan IPS belum dapat melakukan pengelolaan kelas secara optimal lebih banyak bertindak sebagai penyaji informasi dari buku;

5. Guru pendidikan IPS belum berkiprah secara langsung terencana membentuk kemampuan berpikir dan sistem nilai peserta didik;

6. Pendidikan IPS lebih banyak bertindak sebagai pengajar sehingga belum banyak bertindak sebagai panutan; dan

7. Guru pendidikan IPS belum secara optimal memberikan kemudahan bagi para peserta didik perlu bertindak sebagai motivator dalam belajar.

Kelemahan pembelajaran dalam pendidikan IPS sebagaimana yang digambarkan di atas, pada intinya dapat disimpulkan adalah karena terbatasnya aktivitas belajar peserta didik dan sangat dominan nya peran guru dalam proses pembelajaran titik mengajar lebih tampak dari pada kegiatan pembelajaran. Hal ini mengakibatkan lemahnya proses dan pengalaman belajar serta rendahnya hasil belajar. Proses pembelajaran seperti ini menimbulkan kebosanan dan kelelahan pikiran, keterampilan yang diperoleh hanyalah sebatas pengumpulan fakta fakta dan pengetahuan abstrak.

Peserta didik hanya sebatas menghafal, dengan kata lain proses belajar terperangkap kepada "proses menghafalnya" tanpa dihadapkan kepada masalah untuk lebih banyak berpikir dan bertindak sehingga belajar 
hanya menyentuh pengembangan kognitif tingkat rendah belum mengembangkan kemampuan berpikir tingkat tinggi titik pemahaman menjadi dangkal sehingga tidak dapat mengetahui pengetahuan lainnya yang justru dapat membantu untuk menyelesaikan masalah.

Memang hampir semua subjek dalam belajar bisa dipelajari dengan cara menghafal. Namun cara ini sebetulnya akan menimbulkan masalah, karena memorisasi menimbulkan kebosanan dan kelelahan pikiran, belum lagi keterampilan yang diperoleh hanyalah sebatas pengumpulan fakta fakta dan pengetahuan abstrak. Masalah lain yaitu, cara hafalan menyulitkan kita untuk memperluas wawasan wawasan untuk kemudian direalisasikan dengan situasi baru. Peserta didik yang dituntut untuk menghafal tanpa belajar memahami sebuah alasan dibalik fakta atau pengetahuan akan memiliki sedikit pemahaman terhadap sesuatu titik pemahamannya menjadi dangkal sehingga tidak dapat mengetahui pengetahuan lainnya yang justru dapat membantunya untuk menyelesaikan masalah titik tidak ada hal lain yang menyenangkan dengan cara belajar hafalan kecuali mungkin peraihan nilai yang bagus. Namun kenyataannya peserta didik yang menghafal tanpa memahami akan sulit menjelajahi pengetahuan yang sebenarnya.

Belajar dengan cara menghafal membuat peserta didik bergantung pada guru sebagai sumber informasi dan karenanya mereka kurang peduli dengan kekurangannya sendiri titik peserta didik tidak berkeinginan untuk belajar secara lebih mendalam lagi karena informasi sudah tersedia. Belajar seperti ini pada akhirnya dapat 
membentuk sikap peserta didik yang belajar tanpa bertanya, mempercayai segala sesuatu tanpa keraguan dan kurangnya kemampuan pemahaman terhadap informasi-informasi yang kompleks.

Pembelajaran pendidikan IPS di sekolah Seharusnya lebih menekankan pada aspek aspek pengetahuan sikap dan keterampilan dari berbagai permasalahan yang ada di sekitar peserta didik. Guru dituntut untuk mampu memotivasi peserta didik agar aktif, kreatif, dan sistematis terhadap berbagai permasalahan yang ada, mampu memberikan solusi pemecahannya berdasarkan pengetahuan serta pemahamannya yang dimiliki oleh guru, misalnya dengan menerapkan berbagai metode atau pendekatan. Pendekatan yang bisa digunakan, antara lain pendekatan belajar berbasis masalah, pendekatan pembelajaran kooperatif, inkuiri, dan pembelajaran kontekstual (CTL).

Guru dapat mengembangkan materi IPS dengan memperhatikan hal-hal ini: (1) materi ajar memuat masalah sosial yang memang muncul dan nampak dalam lingkungan peserta didik; (2) guru memiliki kedekatan dengan peserta didik sehingga dapat dengan mudah mempengaruhi mereka dengan memberikan gagasan dan pikiran; dan (3) menciptakan suasanan yang kondusif sehingga dapat memunculkan interaksi antara guru dan peserta didik dan komunikasi tersebut terjadi dalam bentuk komunikasi dua arah.

\section{b. Karaktertistik Mata Pelajaran IPS SD}


Karakteristik mata pelajaran IPS tentu saja memiliki perbedaan denggan disipin ilmu lain. IPS merupakan hasil dari integrasi dari berbagai macam disiplin ilmu sosial, sepert: Sejarag, Geografi, Ekonomi, Sosiologi, Huku, dan Budaya. Rumusan IPS berdasarkan kenyataan realita dan kejadian-kejadian atau fenomena sosial melalui pendekatan interdisipliner.

Tujuan utama IPS ialah untuk mengembangkan potensi peserta didik agar peka terhadap masalah sosial yang terjadi di masyarakat, memiliki sikap mental positif terhadap perbaikan segala ketimpangan yang terjadi, dan terampil mengatasi setiap masalah yang terjadi seharihari baik yang menimpa dirinya sendiri maupun yang menimpa masyarakat.

Karakteristik pembelajaran IPS yang dilihat dari aspek tujuan yang cenderung mengarah kepada pemberdayaan intelektual peserta didik maka dalam pelaksanaannya dapat digabungkan dengan pendekatan kontekstual, di mana salah satunya adalah dengan komponen-komponen yang dimiliki pada pendekatan kontekstual tersebut yaitu: konstruktivisme, bertanya, menemukan, masyarakat belajar pemodelan dan penilaian sebenarnya. Berdasarkan hal tersebut dapat dilihat bahwa pemberdayaan intelektual akan dapat dilatih melalui implementasi materi pelajaran IPS yang dikemas dalam pembelajaran IPS yang menggunakan pendekatan kontekstual. Hal ini terutama dapat dilihat dari komponen bertanya, menemukan, dan pemodelan titik dimana peserta didik harus mampu melakukan aktivitas belajar sendiri sesuai dengan tuntunan materi IPS yang 
memanfaatkan sumber belajar dan kemampuan belajar peserta didik sendiri dalam memperoleh pemahaman mengenai apa yang ia pelajari.

Lain halnya dengan Said Hamid Hasan, Mak sundawa (2006) mengkategorisasikan karakteristik pembelajaran IPS yang dilihat dari aspek tujuan ini meliputi tiga aspek yang harus dituju dalam pengembangan pendidikan IPS, yaitu aspek intelektual, kehidupan sosial, dan kehidupan individual. Pengembangan kemampuan intelektual lebih didasarkan pada pengembangan disiplin ilmu itu sendiri serta pengembangan akademik dan thinking skill. Tujuan intelektual berupaya untuk mengembangkan kemampuan peserta didik dalam memahami disiplin ilmu sosial kemampuan berpikir, kemampuan proses dalam mencari informasi dan mengkomunikasikan hasil temuan titik pengembangan kehidupan sosial berkaitan dengan pengembangan kemampuan dan tanggung jawab peserta didik sebagai anggota masyarakat. Tujuan ini mengembangkan kemampuan seperti berkomunikasi, rasa tanggung jawab sebagai warga negara dan warga dunia kemampuan berpartisipasi dalam kegiatan kegiatan kemasyarakatan dan bangsa. Termasuk dalam tujuan ini adalah pengembangan pemahaman dan sikap positif peserta didik terhadap nilai, norma, dan moral yang berlaku dalam masyarakat.

Fokus utama dari program IPS adalah membentuk individu-individu yang memahami kehidupan sosialnya dunia manusia, aktivitas, dan interaksinya yang ditujukan untuk menghasilkan anggota masyarakat yang bebas, 
yang mempunyai rasa tanggung jawab untuk melestarikan, melanjutkan, dan memperluas nilai-nilai dan ide-ide masyarakat bagi generasi masa depan.

Ada tiga kajian utama berkenaan dengan dimensi tujuan pembelajaran IPS di SD yaitu: a) Pengembangan kemampuan berpikir peserta didik, b) pengembangan nilai dan etika, dan c) pengembangan tanggung jawab dan partisipasi sosial. Ketika dimensi tersebut secara rinci dapat dijelaskan berikut ini:

1. Pengembangan Kemampuan Berpikir Peserta didik

Pengembangan kemampuan intelektual adalah pengembangan kemampuan peserta didik dalam berpikir tentang ilmu-ilmu sosial dan masalah kemasyarakatan. Udin S Winataputra (1996) mengemukakan bahwa dimensi intelektual merujuk pada ranah kognitif terutama yang berkenaan dengan proses berpikir atau pembelajaran yang menyangkut proses kognitif bertaraf tinggi dari mulai kemampuan pemahaman sampai evaluasi. Hamid Hasan (1998) menambahkan bahwa pada proses berpikir mencakup pula kemampuan dalam mencari informasi, mengolah informasi, dan mengkomunikasikan temuan.

Pengembangan kemampuan berpikir dalam bidang studi pendidikan IPS yang paling penting adalah menumbuhkan berpikir kreatif dan inovatif kreatif atau kreativitas adalah kemampuan seseorang untuk melahirkan sesuatu yang baru (produk), baik berupa gagasan maupun karya nyata yang relatif berbeda dengan apa yang telah ada sebelumnya.

2. Pengembangan Nilai dan Etika 
Pengembangan nilai dan etika adalah pengembangan kemampuan peserta didik dalam memahami dan mempelajari nilai-nilai yang berlaku di masyarakat dan tata cara berperilaku yang perlu untuk dipatuhi dan ditunjukkan ke masyarakat.

3. Pengembangan Tanggung Jawab dan Partisipasi Sosial

Dimensi yang ketiga adalah mengembangkan tanggung jawab dan partisipasi sosial yakni mengembangkan tujuan IPS dalam membentuk warga negara yang baik. Warga negara yang baik adalah warga negara yang berpartisipasi aktif dan terlibat dalam kehidupan bermasyarakat.

Tujuan utama IPS ialah untuk mengembangkan potensi peserta didik agar peka terhadap masalah sosial yang terjadi di masyarakat, memiliki sikap mental positif terhadap perbaikan segala ketimpangan yang terjadi, dan terampil mengatasi setiap masalah yang terjadi seharihari baik yang menimpa dirinya sendiri maupun yang menimpa masyarakat.

Tujuan tersebut dapat dicapai manakala programprogram pembelajaran IPS di sekolah diorganisasikan secara baik. Dari rumusan tujuan tersebut dapat dirinci sebagai berikut (Awan Mutakin, 1998):

1. Memiliki kesadaran dan kepedulian terhadap masyarakat atau lingkungannya, melalui pemahaman terhadap nilai-nilai sejarah dan kebudayaan masyarakat.

2. Mengetahui dan memahami konsep dasar dan mampu menggunakan metode yang diadaptasi dari ilmu-ilmu 
sosial yang kemudian dapat digunakan untuk memecahkan masalah-masalah sosial.

3. Mampu menggunakan model-model dan proses berpikir serta membuat keputusan untuk menyelesaikan isu dan masalah yang berkembang di masyarakat.

4. Menaruh perhatian terhadap isu-isu dan masalahmasalah sosial, serta mampu membuat analisis yang kritis, selanjutnya mampu mengambil tindakan yang tepat.

5. Mampu mengembangkan berbagai potensi sehingga mampu membangun diri sendiri agar survive yang kemudian bertanggung jawab membangun masyarakat. pengembangan keterampilan pembuatan keputusan.

6. Memotivasi seseorang untuk bertindak berdasarkan moral.

7. Fasilitator di dalam suatu lingkungan yang terbuka dan tidak bersifat menghakimi.

8. Mempersiapkan peserta didik menjadi warga negara yang baik dalam kehidupannya "to prepare students to be well-functioning citizens in a democratic society" dan mengembangkan kemampuan peserta didik mengunakan penalaran dalam mengambil keputusan pada setiap persoalan yang dihadapinya.

9. Menekankan perasaan, emosi, dan derajat penerimaan atau penolakan peserta didik terhadap materi pembelajaran IPS yang diberikan. 


\section{Tabel 1.1. Tabel Uraian Revisi Kompetensi Inti Tingkat Pendidikan Dasar}

\begin{tabular}{|c|c|}
\hline Kompetensi Inti & Deskripsi Kompetensi \\
\hline Sikap Spiritual & $\begin{array}{l}\text { 1. Menerima, menjalankan, dan } \\
\text { menghargai ajaran agama yang } \\
\text { dianutnya. }\end{array}$ \\
\hline Sikap Sosial & $\begin{array}{l}\text { 2. Menunjukkan perilaku: } \\
\text { a. jujur, } \\
\text { b. disiplin, } \\
\text { c. santun, } \\
\text { d. percaya diri, } \\
\text { e. peduli, dan } \\
\text { f. bertanggung jawab dalam } \\
\text { berinteraksi dengan keluarga, } \\
\text { teman, guru, dan tetangga, dan } \\
\text { negara. }\end{array}$ \\
\hline Pengetahuan & $\begin{array}{l}\text { 3. Memahami pengetahuan faktual, } \\
\text { konseptual, prosedural, dan } \\
\text { metakognitif pada tingkat dasar dengan } \\
\text { cara: } \\
\text { a. mengamati, } \\
\text { b. menanya, dan } \\
\text { c. mencoba Berdasarkan rasa ingin } \\
\text { tahu tentang dirinya, makhluk } \\
\text { ciptaan Tuhan dan kegiatannya, dan } \\
\text { benda-benda yang dijumpainya di } \\
\text { rumah, di sekolah, dan tempat } \\
\text { bermain. }\end{array}$ \\
\hline Keterampilan & $\begin{array}{l}\text { 4. Menunjukkan keterampilan berfikir } \\
\text { dan bertindak: } \\
\text { a. kreatif } \\
\text { b. produktif, } \\
\text { c. kritis, } \\
\text { d. mandiri, } \\
\text { e. kolaboratif, dan }\end{array}$ \\
\hline
\end{tabular}




\begin{tabular}{|l|l|}
\hline f. & $\begin{array}{l}\text { komunikatif dalam bahasa yang } \\
\text { jelas, sistematis, logis dan kritis, } \\
\text { dalam karya yang estetis, dalam } \\
\text { gerakan yang mencerminkan anak } \\
\text { sehat, dan tindakan yang } \\
\text { mencerminkan perilaku anak sesuai } \\
\text { dengan tahap perkembangannya. }\end{array}$ \\
\hline
\end{tabular}

\section{c. Dimensi Pembelajaran IPS}

Pencapaian pembelajaran pendidikan IPS di persekolahan diperlukan pemahaman dan pengembangan program pendidikan yang komprehensif. Program pendidikan IPS yang komprehensif tersebut menurut Sapriya (2009:48-56) adalah program pendidikan yang mencakup empat dimensi, yaitu dimensi pengetahuan (knowledge), dimensi keterampilan (skill), dimensi nilai dan sikap (value and attitude), dan dimensi tindakan (action). Lebih perinci keempat dimensi tersebut dapat dijabarkan sebagai berikut:

1. Dimensi pengetahuan (knowledge)

Pengetahuan adalah kemahiran dan pemahaman terhadap sejumlah informasi dan ide-ide. Tujuan pengembangan pengetahuan ini adalah untuk membantu peserta didik dalam belajar untuk memahami lebih banyak tentang dirinya, fisiknya, dan dunia sosial serta lingkungan sekitarnya. Dimensi yang menyangkut pengetahuan sosial mencakup: a) fakta, b) konsep, dan c) generalisasi yang dipahami peserta didik.

2. Dimensi Keterampilan 
Keterampilan adalah pengembangan kemampuankemampuan tertentu sehingga digunakan pengetahuan yang diperolehnya. Keterampilan ini dalam pendidikan IPS terwujud dalam bentuk kecakapan mengolah dan menerapkan informasi yang penting untuk mempersiapkan peserta didik menjadi warga negara yang mampu berpartsisipasi secara cerdas dalam masyarakat demokratis. Keterampilan tersebut dalam mencakup keterampilan meneliti, keterampilan berpikir, keterampilan partisipasi, dan keterampilan berkomunikasi.

3. Dimensi Nilai dan Sikap

Nilai dan sikap merupakan seperangkat keyakinan atau prinsip perilaku yang telah mempribadi dalam diri seseorang atau kelompok masyarakat tertentu yang terungkap ketika berpikir dan bertindak. Nilai adalah kemahiran memegang sejumlah komitmen yang mendalam, mendukung ketika sesuatu dianggap penting dengan tindakan yang tepat. Adapun sikap adalah kemahiran mengembangkan dan menerima keyakinan, ketertarikan, pandangan, dan kecenderungan tertentu

4. Dimensi Tindakan

Tindakan sosial ini merupakan dimensi IPS yang penting karena tindakan sosial dapat memungkinkan peserta didik menjadi peserta didik yang aktif secara konkrit, belajar dari apa yang diketahui dan dipikirkan tentang isu-isu sosial untuk dipecahkan sehingga jelas apa yang dilakukan dan bagaimana caranya dengan 
demikian peserta didik akan belajar menjadi warga negara yang efektif di masyarakat.

Berikut adalah muatan IPS pada sekolah dasar/paket A:

\section{Tabel 1.2. Muatan Ilmu Pengetahuan Sosial pada SD/MI/SDLB/PAKET A}

\begin{tabular}{|c|c|c|}
\hline $\begin{array}{c}\text { Tingkat } \\
\text { Kompetensi }\end{array}$ & Kompetensi & $\begin{array}{c}\text { Ruang Lingkup } \\
\text { Materi }\end{array}$ \\
\hline $\begin{array}{l}\text { Tingkat } \\
\text { Pendidikan } \\
\text { Dasar (mulai } \\
\text { Kelas IV-VI) }\end{array}$ & 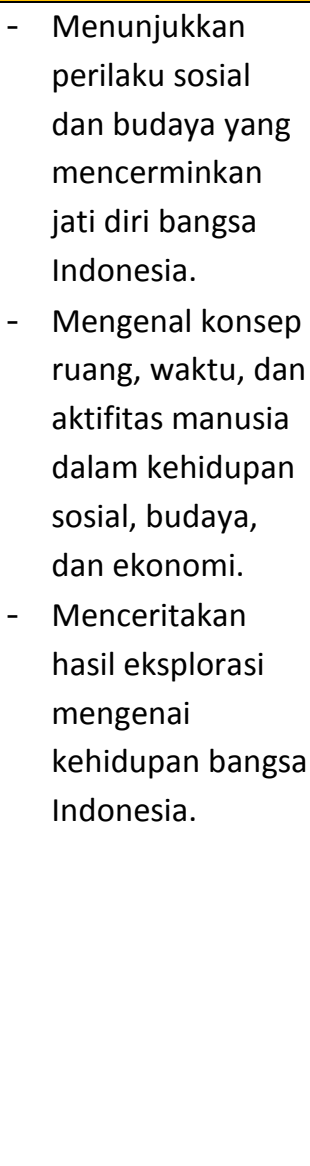 & $\begin{array}{l}\text { Manusia, tempat, } \\
\text { dan lingkungan } \\
\text { - } \text { Wilayah geografis } \\
\text { tempat tinggal } \\
\text { bangsa Indonesia. } \\
\text { - } \text { Konektivitas dan } \\
\text { interaksi sosial } \\
\text { kehidupan bangsa } \\
\text { di wilayah negara } \\
\text { Indonesia. } \\
\text { Waktu, } \\
\text { keberlanjutan, dan } \\
\text { perubahan } \\
\text { - Perkembangan } \\
\text { kehidupan bangsa } \\
\text { Indonesia dalam } \\
\text { waktu sejak masa } \\
\text { praaksara hingga } \\
\text { masa Islam. } \\
\text { Sistem sosial dan } \\
\text { budaya } \\
\text { - Kehidupan }\end{array}$ \\
\hline
\end{tabular}




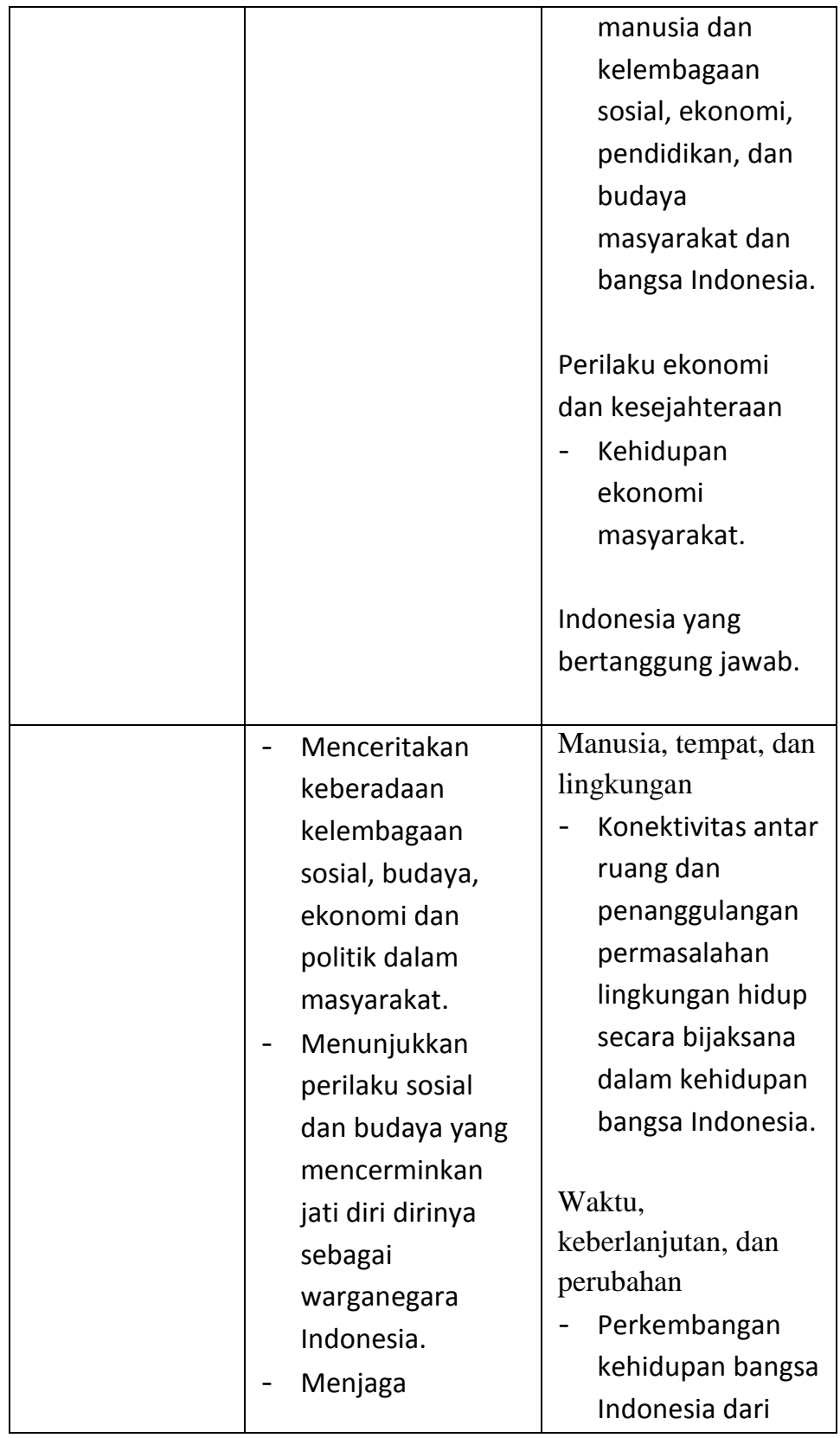




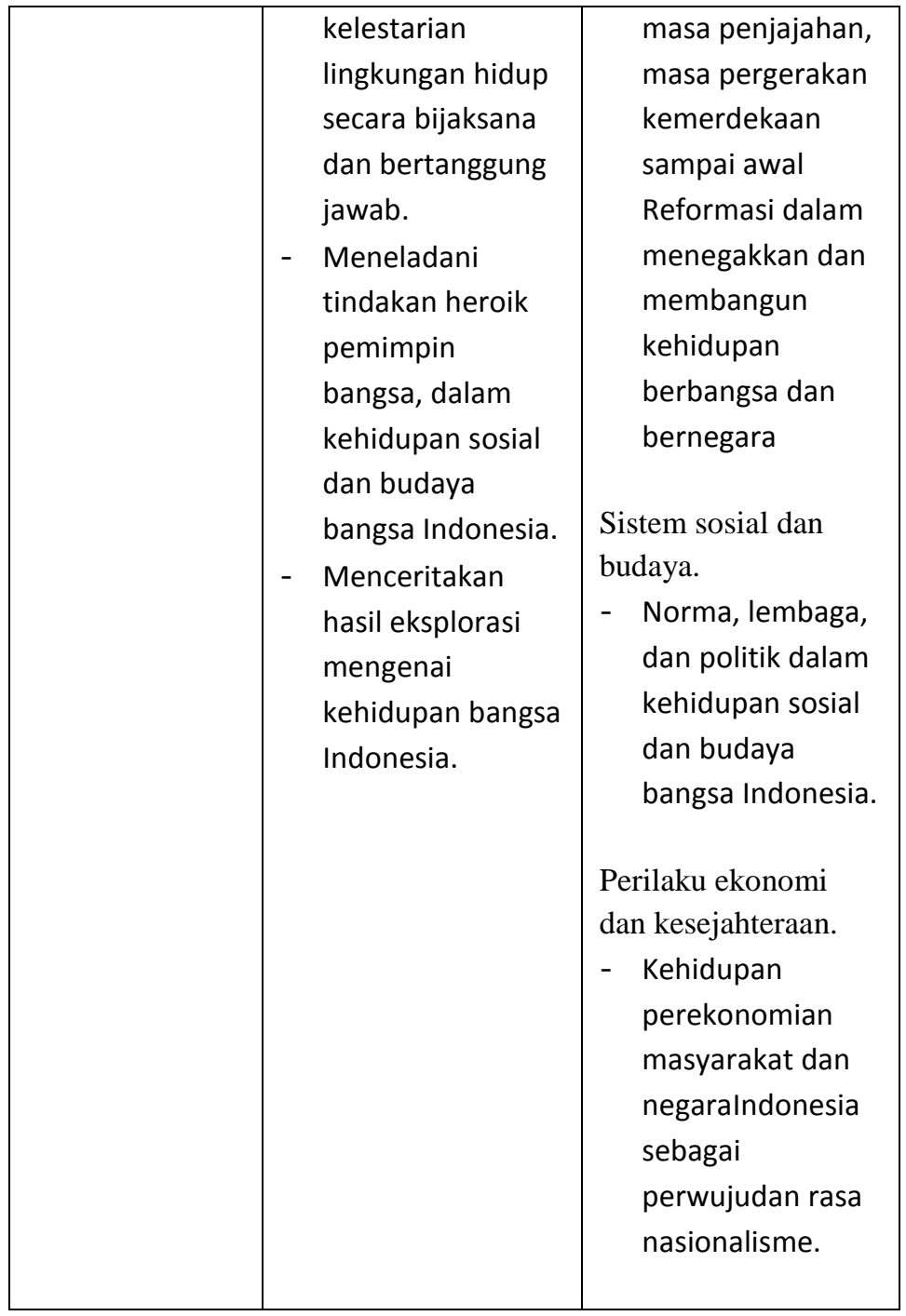


1. Pembelajaran pendidikan IPS di sekolah seharusnya lebih menekankan pada aspek-aspek pengetahuan, sikap, dan keterampilan dari berbagai permasalahan yang ada di sekitar peserta didik.

2. Pelajaran IPS di SD mengajarkan konsep-konsep esensi ilmu sosial untuk membentuk subjek didik menjadi warga negara yang baik.

3. Ada tiga kajian utama berkenaan dengan dimensi tujuan pembelajaran IPS di SD, yaitu: a) pengembangan kemampuan berpikir peserta didik; b) pengembangan nilai dan etika; dan c) pengembangan tanggung jawab dan partisipasi sosial.

\section{KERJAKAN AKU!}

Mengapa mata pelajaran IPS sangat perlu diberikan di jenjang sekolah dasar?

\section{DAFTARRUJUKAN}

Hasan, S.H. (1996). Pendidikan Ilmu Sosial. Jakarta: Depdikbud 
Mutakin, A. (1992). Pendidikan Ilmu Sosial. Bandung: Anggita Pustaka Mandiri.

Sapriya. (2002). Studi Sosial: Konsep dan Model

Pembelajaran. Bandung: Buana Nusantara

Somantri, M.N. (2001). Menggagas Pembaharuan

Pendidikan IPS. Bandung: UPI bekerja sama dengan PT Remaja Rosdakarya.

Winataputra, U.S. (1997). Belajar dan Pembelajaran IPS. Jakarta: Proyek Strata DIII. 


\section{BAB II \\ PEMBELAJARAN IPS MENGGUNAKAN METODE \\ SIMULASI}

TUJUAN PEMBELAJARAN

- Mahasiswa mampu menyebutkan hakikat dan pengertian metode simulasi

- Mahasiswa mampu menyebutkan tujuan metode simulasi

- Mahasiswa mampu mengidentifikasi kelebihan dan kekurangan metode simulasi

- Mahasiswa dapat menganalisis implementasi metode simulasi dalam pembelajaran IPS

\section{a. Hakikat dan Pengertian Metode Simulasi}

Simulasi berasal dari kata simulate yang berarti purapura atau berbuat seolah-olah atau simulation yang berarti tiruan yang hanya berpura-pura saja. Sebagai metode mengajar simulasi dapat diartikan sebagai suatu kegiatan yang menggambarkan kejadian atau peristiwa sebenarnya.

Menurut pusat bahasa Depdiknas (2005) simulasi adalah satu metode pelatihan yang memperagakan sesuatu dalam bentuk tiruan (imitasi) yang mirip dengan keadaan yang sesungguhnya simulasi: penggambaran suatu sistem atau proses dengan peragaan memakai model statistik atau pemeran.

Udin syaefudin Sa'ud (2005: 129) simulasi adalah sebuah replikasi atau visualisasi dari perilaku sebuah 
sistem, misalnya sebuah perencanaan pendidikan, yang berjalan pada kurun waktu yang tertentu. Jadi dapat dikatakan bahwa simulasi Itu adalah sebuah model yang berisi seperangkat variabel yang menampilkan ciri utama dari sistem kehidupan yang sebenarnya. Simulasi memungkinkan keputusan-keputusan yang menentukan Bagaimana ciri-ciri utama itu bisa dimodifikasi secara nyata.

Sri Anitah, W., dkk. (2007: 522) metode simulasi merupakan salah satu metode pembelajaran yang dapat digunakan dalam pembelajaran kelompok. Proses pembelajaran yang menggunakan metode simulasi cenderung objek nya bukan benda atau kegiatan yang sebenarnya melainkan kegiatan mengajar yang bersifat pura-pura. Kegiatan simulasi dapat dilakukan oleh peserta didik pada kelas tinggi di sekolah dasar.

Dalam pembelajaran yang menggunakan metode simulasi, peserta didik dibina kemampuannya berkaitan dengan keterampilan berinteraksi dan berkomunikasi dalam kelompok. Di samping itu, dalam metode simulasi peserta didik diajak untuk dapat bermain peran beberapa perilaku yang dianggap sesuai dengan tujuan pembelajaran. Model mengajar ini berdasarkan kepada teori Sarene Bookock, Harold Guetzkow yang tujuannya dirancang untuk membantu peserta didik mengalami bermacam-macam proses dan kenyataan sosial, dan untuk menguji reaksi mereka serta untuk memperoleh keterampilan pembuatan keputusan (Moh. Surya, 2003: 125). 
Model pembelajaran simulasi merupakan model pembelajaran yang membuat suatu peniruan terhadap sesuatu yang nyata terhadap keadaan sekelilingnya (state of affaris) atau proses itu model pembelajaran ini dirancang untuk membantu peserta didik mengalami bermacam-macam proses dan kenyataan sosial dan untuk menguji reaksi mereka, serta untuk memperoleh konsep keterampilan pembuatan keputusan titik model pembelajaran ini diterapkan di dalam dunia pendidikan dengan tujuan mengaktifkan kemampuan yang dianalogikan dengan proses sibernetika. Pendekatan simulasi dirancang agar mendekati kenyataan di mana gerakan yang dianggap Kompleks sengaja dikontrol, misalnya dalam proses simulasi ini dilakukan dengan menggunakan simulator.

Pelaksanaan simulasi haruslah terjadi proses proses kegiatan yang memaksimalkan domain afektif (contoh: menyenangkan, menggairahkan, suka, sedih terharu, simpati, solidaritas, gotong royong dan sebagainya), domain psikomotorik (contoh: keterampilan berbicara, bertanya, berdebat, mengemukakan pendapat, memimpin, dan sebagainya), dan domain kognitif (contoh: memahami konsep-konsep tertentu, pengertian teori dan sebagainya juga dalam pelaksanaan simulasi hendaklah dilakukan korelasi antara berbagai disiplin ilmu pengetahuan).

\section{b. Tujuan Metode Simulasi}

Metode simulasi bertujuan untuk: 1) Melatih keterampilan tertentu baik bersifat profesional maupun 
bagi kehidupan sehari-hari, 2) Memperoleh pemahaman tentang suatu konsep atau prinsip, 3) melatih memecahkan masalah, 4) meningkatkan keaktifan belajar, 5) memberikan motivasi belajar kepada peserta didik, 6) melatih peserta didik untuk mengadakan kerjasama dalam situasi kelompok, 7) menumbuhkan daya kreatif peserta didik, dan 8) melatih peserta didik untuk memahami dan menghargai pendapat serta peranan orang lain.

Dengan demikian, penggunaan metode simulasi dalam proses pembelajaran sesuai dengan kecenderungan pembelajaran modern yang menuju kepada pembelajaran peserta didik yang bersifat individu dan kelompok kecil, heuristik (mencari sendiri perolehan) dan aktif. Sesuai dengan hal ini simulasi menurut Derick, U dan Mc Aleese, R., bahwa simulasi memiliki 3 sifat utama yang dapat meningkatkan keaktifan peserta didik dalam proses pembelajaran, yaitu: 1) simulasi adalah bentuk teknik mengajar yang berorientasi pada keaktifan peserta didik dalam pembelajaran di kelas, baik guru maupun peserta didik mengambil peran di dalamnya, 2) simulasi pada umumnya bersifat pemecahan masalah yang sangat berguna untuk melatih peserta didik melakukan pendekatan interdisiplin di dalam pembelajaran. Disamping itu, dapat juga mempraktikkan keterampilan keterampilan sosial yang relevan dengan kehidupan masyarakat, 3) simulasi adalah model pembelajaran yang bersifat dinamis dalam arti sangat sesuai untuk menghadapi situasi-situasi yang berubah yang membutuhkan Keluwesan dalam berpikir dan 
memberikan jawaban terhadap keadaan yang cepat berubah.

\section{c. Kelebihan dan Kekurangan Metode Simulasi}

1. Kelebihan Metode Simulasi

Pemanfaatan model pembelajaran simulasi dalam penerapannya sangat banyak memiliki kelebihan yang dapat diperoleh antara lain:

a) Memupuk daya cipta peserta didik.

b) Sekalipun tujuan utamanya simulasi itu sebagai alat untuk belajar tetapi juga peserta didik merasa bergairah.

c) Simulasi dapat dijadikan sebagai bekal peserta didik nanti apabila menghadapi hal-hal yang dihadapi pada situasi yang sebenarnya.

d) Simulasi merangsang peserta didik untuk menjadi biasa dan terampil dalam menanggapi dan bertindak secara spontan.

e) Memupuk keberanian dan kemantapan penampilan peserta didik di depan orang banyak.

f) Memperkaya pengetahuan sikap dan keterampilan serta pengalaman tidak langsung.

g) Peserta didik berkesempatan untuk menjalankan yang terpendam sehingga mendapat kepuasan, kesegaran,

2. Kekurangan Metode Simulasi

Selain kelebihannya, metode simulasi ini juga tidak terlepas dari kekurangannya, antara lain: 
a) Pengalaman yang didapat dari simulasi tidak selalu tepat dan sempurna dengan kenyataan kehidupannya.

b) pelaksanaan simulasi sering menjadi kaku, bahkan salah arah, karena kurangnya pengalaman peserta didik terhadap masalah-masalah sosial yang diperankan.

c) Faktor emosional seperti rasa malu, ragu-ragu atau takut akan mempengaruhi peserta didik dalam melakukan simulasi.

d) Simulasi menuntut imajinasi peserta didik dan guru yang memadai.

\section{d. Implementasi Metode Simulasi dalam Pembelajaran IPS SD}

Pembelajaran IPS dengan menggunakan metode simulasi akan melatih pola pikir peserta didik sehingga ia akan belajar mengemukakan pendapat, mengungkapkan pengalaman dan pengetahuannya, belajar berbeda pendapat, belajar menghormati dan megnhargai pendapat orang lain atau bahkan mempertahankan pendapat sesuai dengan yang ia yakini berdasarkan alasan yang tegas.

Pembelajaran IPS dengan menggunakan metode simulasi merupakan suatu pendekatan atau strategi pembelajaran yang memunculkan berbagai macam kehidupan di masyarakat yang kemudian diangkat menjadi sebuah materi pembelajaran dalam kegiatan belajar mengajar di sekolah.

Melalui kegiatan ini peserta didik diajak untuk mencari, menganalisis, dan memecahkan maslah berdasarkan persepsinya sendiri meskipun akan terjadi perbedaan persepsi 
dengan peserta didik yang lainnya. Justru karena itu peserta didik akan terangsang (kemampuan dan keterampilan) berpikir kritis yang nantinya akan dapat mengembangkan aktivitas peserta didik.

Prosedur dalam mengaplikasikan metode simulasi yang harus ditempuh dalam pembelajaran adalah sebagai berikut:

1. Menetapkan topik simulasi yang diarahkan oleh gutu.

2. Menetapkan kelompok dan topik-topik yang akan dibahas.

3. Simulasi diawali dengan petunjuk dari guru tentang prosedur, teknik, dan peran yang dimainkan.

4. Proses pengamatan terhadap proses, peran, teknik, dan prosedur dapat dilakukan dengan diskusi.

5. Kesimpulan dan saran dari kegiatan simulasi.

Langkah-langkah simulasi menurut Trianto (2010: 141142), antara lain:

\section{Tahapan persiapan}

a. Menetapkan topik atau masalah serta tujuan yang hendak dicapai oleh simulasi.

b. Guru memberikan gambaran masalah dalam situasi yang akan disimulasikan.

c. Guru menetapkan pemain yang akan terlibat dalam simulasi, peranan yang harus dimainkan oleh para pemeran, serta waktu yang disediakan.

d. Guru memberikan kesempatan kepada peserta didik untuk bertanya khususnya kepada peserta didik yang terlibat dalam pemeranan simulasi.

\section{Pelaksanaan Simulasi}

a. Simulasi mulai dimainkan oleh kelompok pemeran.

b. Para peserta didik lainnya mengikuti dengan penuh perhatian.

c. Guru hendaknya memberikan bantuan kepada pemeran yang mendapat kesulitan. 
d. Simulasi hendaknya dihentikan pada saat puncak. Hal ini dimaksudkan untuk mendorong peserta didik berpikir dalam menyelesaikan masalah yang sedang disimulasikan.

\section{Penutup}

a. Melakukan diskusi baik tentang jalannya simulasi maupun materi cerita yang disimulasikan. Guru harus mendorong agar peserta didik dapat memberikan kritik dan tanggapan terhadap proses pelaksanaan simulasi.

b. Merumuskan kesimpulan

\section{SIMPULAN}

1. Dalam pembelajaran yang menggunakan metode simulasi, peserta didik akan dibina kemampuannya berkaitan dengan keterampilan berinteraksi dan berkomunikasi dalam kelompok. Disamping itu, dalam metode simulasi peserta didik diajak untuk dapat bermain peran beberapa perilaku yang dianggap sesuai dengan tujuan pembelajaran.

2. Metode simulasi adalah bentuk teknik mengajar yang berorientasi pada keaktifan peserta didik dalam pembelajaran

3. Dalam menerapkan metode simulasi, kondisi dan kemampuan peserta didik serta guru harus diperhatikan untuk menunjang metode tersebut supaya berjalan maksimal.

\section{KERJAKAN AKU!}

Buatlah skenario sederhana simulasi yang sesuai dengan usia sekolah dasar dan tentu saja, diterapkan dalam mata pelajaran IPS! 


\section{DAFTARRUJUKAN}

Sa'ud, U.S., \& Sutarsih. (2007). Pengembangan Profesi Guru. Bandung: Alfabeta.

Surya, H.M. (2003). Kapita Selekta Pendidikan SD. Jakarta: UT

Trianto. (2010). Mengembangkan Model Pembelajaran Tematik. Jakarta: PT. Prestasi Pustakaraya. 


\section{BAB III}

\section{PENDEKATAN PEMBELAJARAN KONSTRUKTIVISME}

\section{TUJUAN PEMBELAJARAN}

- Mahasiswa mampu menyebutkan pengertian konstruktivisme

- Mahasiswa mampu mengidentifikasi ciri-ciri pembelajaran konstruktivisme

- Mahasiswa mampu menganalisis implementasi pendekatan konstruktivisme dalam pembelajaran IPS SD

- Mahasiswa mampu mensimulasikan metode mengajar dalam pendekatan konstruktivisme

\section{a. Pengertian Konstruktivisme}

Konstruktivisme merupakan metode pembelajaran yang lebih menekankan pada proses dan kebebasan dalam menggali pengetahuan serta upaya dalam mengkonstruksi pengalaman atau dengan kata lain teori ini memberikan keaktifan terhadap peserta didik untuk belajar menemukan sendiri kompetensi, pengetahuan atau teknologi, dan hal lain yang diperlukan guna mengembangkan dirinya sendiri. Dalam pembelajaran konstruktivis, peserta didik diberi kebebasan untuk mengemukakan gagasannya dengan bahasa sendiri, untuk memberikan pendapatnya tentang pengalamannya sehingga peserta didik dapat menjadi lebih kreatif dan imajinatif serta dapat menciptakan lingkungan belajar yang kondusif. 
Menurut Piaget (1971), pengetahuan itu akan bermakna bila dicari dan ditemukan sendiri oleh peserta didik bukan hasil pemberitahuan dari orang lain, termasuk guru. Selanjutnya, Piaget dalam Sanjaya (2007:194) menyatakan bahwa setiap individu berusaha dan mampu mengembangkan pengetahuannya sendiri melalui skema yang ada lam struktur kognitifnya. Skema ini terus menerus diperbaharui dan diubah melalui proses asimilasi dan akomodasi. Dengan demikian, tugas guru adalah memotivasi peserta didik untuk mengembangkan skema yang terbentuk melalui proses asimilasi dan akomodasi tersebut.

Unsur-unsur penting dalam teori konstruktivistik:

1. Memperhatikan dan memanfaatkan pengetahuan awal peserta didik

2. Pengalaman belajar yang autentik dan bermakna

3. Adanya lingkungan social yang kondusif

4. Adanya dorongan agar peserta didik mandiri

5. Adanya usaha untuk mengenalkan peserta didik tentang dunia ilmiah

Secara garis besar, prinsip-prinsip teori konstruktivistik adalah sebagai berikut:

1. Pengetahuan dibangun oleh peserta didik sendiri.

2. Pengetahuan tidak dapat dipindahkan dari guru ke murid, kecuali hanya dengan keaktifan murid sendiri untuk menalar.

3. Murid aktif mengkonstruksi secara terus menerus, sehingga selalu terjadi perubahan konsep ilmiah.

4. Guru sekedar membantu menyediakan saran dan situasi agar proses konstruksi berjalan lancar. 
5. Menghadapi masalah yang relevan dengan peserta didik.

6. Struktur pembelajaran seputar konsep utama pentingnya sebuah pernyataan.

7. Mencari dan menilai pendapat peserta didik.

8. Menyesuaikan kurikulum untuk menanggapi anggapan peserta didik.

\section{b. Ciri-ciri Pembelajaran Konstruktivisme}

Adapun menurut Siroj, ciri-ciri pembelajaran yang konstruktivis adalah meliputi:

1. Menyediakan pengalaman belajar dengan mengaitkan pengetahuan yang telah dimiliki peserta didik sedemikian rupa sehingga belajar melalui proses pembentukan pengetahuan;

2. Menyediakan berbagai alternatif pengalaman belajar, tidak semua mengerjakan tugas yang sama, misalnya suatu masalah dapat diselesaikan dengan berbagai cara;

3. Mengintegrasikan pembelajaran dengan situasi yang realistik dan relevan dengan melibatkan pengalaman konkrit, misalnya untuk memahami suatu konsep melalui kenyataan kehidupan seharihari;

4. Mengintegrasikan pembelajaran sehingga memungkinkan terjadinya transmisi sosial yaitu terjadinya interaksi dan kerja sama seseorang dengan orang lain atau dengan lingkungannya, misalnya interaksi dan kerjasama antara peserta didik, guru, dan peserta didik-peserta didik; 
5. Memanfaatkan berbagai media termasuk komunikasi lisan dan tertulis sehingga pembelajaran menjadi lebih efektif; dan

6. Melibatkan peserta didik secara emosional dan sosial sehingga menjadi menarik dan peserta didik mau belajar.

\section{c. Implementasi Pendekatan Konstruktivisme}

Adapun implikasi dari teori belajar konstruktivisme dalam pendidikan anak (Poedjiadi, 1999: 63) adalah sebagai berikut:

1. Tujuan pendidikan menurut teori belajar konstruktivisme adalah menghasilkan individu atau anak yang memiliki kemampuan berfikir untuk menyelesaikan setiap persoalan yang dihadapi,

2. Kurikulum dirancang sedemikian rupa sehingga terjadi situasi yang memungkinkan pengetahuan dan keterampilan dapat dikonstruksi oleh peserta didik. Selain itu, latihan memcahkan masalah seringkali dilakukan melalui belajar kelompok dengan menganalisis masalah dalam kehidupan sehari-hari, dan

3. Peserta didik diharapkan selalu aktif dan dapat menemukan cara belajar yang sesuai bagi dirinya. Guru hanyalah berfungsi sebagai mediator, fasilitor, dan teman yang membuat situasi yang kondusif untuk terjadinya konstruksi pengetahuan pada diri peserta didik. 
Dikatakan juga bahwa pembelajaran yang memenuhi metode konstruktivis hendaknya memenuhi beberapa prinsip, yaitu:

1. Menyediakan pengalaman belajar yang menjadikan peserta didik dapat melakukan konstruksi pengetahuan;

2. Pembelajaran dilaksanakan dengan mengkaitkan kepada kehidupan nyata;

3. Pembelajaran dilakukan dengan mengkaitkan kepada kenyataan yang sesuai;

4. Memotivasi peserta didik untuk aktif dalam pembelajaran;

5. Pembelajaran dilaksanakan dengan menyesuaikan kepada kehidupan sosial peserta didik;

6. Pembelajaran menggunakan barbagai sarana;

7. Melibatkan peringkat emosional peserta didik dalam mengkonstruksi pengetahuan peserta didik (Knuth \& Cunningham,1996).

Pandangan konstruktivisme menempatkan peserta didik sebagai pusat atau pelaku utama dalam pembelajaran, hal ini selaras dengan pemikiran Budiningsih (2005:58) bahwa belajar merupakan proses pembentukan pengetahuan yang dilakukan oleh peserta didik. Ia harus aktif melakukan kegiatan, aktif berpikir, menyusun konsep dan memberi makna tentang hal-hal yang sedang dipelajari. Peserta didik dianggap sudah mempunyai kemampuan awal yang akan menjadi dasar dalam mengkonstruksi pengetahuan yang baru. Oleh karena itu, 
konstruktivisme mempunyai beberapa konsep umum, seperti dibawah ini:

1. Peserta didik aktif membina pengetahuan berasaskan pengalaman yang sudah ada;

2. Dalam konteks pembelajaran, peserta didik seharusnya membina sendiri pengetahuan mereka;

3. Pentingnya membina pengetahuan secara aktif oleh peserta didik sendiri melalui proses saling mempengaruhi antara pembelajaran terdahulu dengan pembelajaran terbaru;

4. Unsur penting dalam teori ini ialah seseorang membina pengetahuan dirinya secara aktif dengan cara membandingkan informasi baru dengan pemahamannya yang sudah ada;

5. Ketidakseimbangan merupakan faktor motivasi pembelajaran yang utama. Faktor ini berlaku apabila seorang peserta didik menyadari gagasangagasannya tidak konsisten atau sesuai dengan pengetahuan ilmiah; dan

6. Bahan pengajaran yang disediakan perlu mempunyai perkaitan dengan pengalaman peserta didik untuk menarik minat belajar peserta didik.

Peran guru dalam belajar konstruktivisme adalah membantu agar proses pengkonstruksian pengetahuan oleh peserta didik berjalan lancar. Berikut adalah peranan guru dalam pembelajaran menurut pandangan konstruktivisme:

1. Berusaha menciptakan kelas yang dapat membuat peserta didik berinteraksi; 
2. Mendorong para peserta didik untuk selalu bekerja sama dan munculnya inisiatif bekerjasama tersebut mendapat penghargaan;

3. Memberikan kesadaran kepada peserta didik bahwa pelajaran yang dipelajarinya bukanlah sesuatu yang berdiri sendiri, guru memberukan tugas-tugas dan materi interdisiplin. Untuk itu, guru lain dari belakang studi yang berbeda dapat hadir di suatu kelas untuk menyaksikan dan memberikan penilaian terhadap kemajuan belajar peserta didik;

4. Memberikan ruang kepada peserta didik yang suka melakukan sesuatu yang beresiko, misalnya dengan memberikan tugas-tugas yang penuh tantangan; dan

5. Menciptakan suasana kolaboratif di dalam kelas. Karena itu guru perlu menghindari munculnya kebiasaan peserta didik yang acap kali bertindak "menang" sendiri dan tidak mau menerima dan menghargai pendapat temannya.

\section{d. Metode Mengajar dalam Pendekatan Konstruktivisme}

Model dan metode pembelajaran merupakan hal yang penting dalam pembelajaran di kelas, karena dengan model pembelajaran tersebut guru dapat menciptakan kondisi belajar yang mendukung pencapaian tujuan pembelajaran. Selain itu, model pembelajaran yang dipilih dan digunakan dengan baik oleh pendidik dalam mendorong peserta didik untuk 
aktif mengikuti kegiatan belajar di dalam kelas. Pemilihan model pembelajaran harus dilandaskan pada pertimbangan menempatkan peserta didik sebagai subjek belajar yang tidak hanya menerima secara pasif apa yang disampaikan oleh pendidik. Pendidik harus menempatkan peserta didik sebagai insan yang secara alami memiliki pengalaman, pengetahuan, keinginan, dan pikiran yang dapat dimanfaatkan untuk belajar, baik secara individu maupun secara kelompok. Model yang dipilih oleh pendidik adalah model yang dapat membuat peserta didik mempunyai keyakinan bahwa dirinya mampu belajar. Selain itu, model pembelajaran yang dapat memanfaatkan potensi peserta didik seluas-luasnya.

Pada hakikatnya pembelajaran merupakan kegiatan yang dilakukan untuk menciptakan suasana atau memberikan pelayanan agar peserta didik belajar. Dalam menciptakan suasanan atau pelayanan, hal yang esensial bagi guru adalah memahami bagaimana murid-muridnya memperoleh pengetahuan, maka ia dapat menentukan strategi atau metode-metode pembelajaran yang tepat bagi murid-muridnya. Terjadinya proses belajar pada murid yang sedang belajar berlangsung secara mental. Namun dari berbagai hasil penelitian atau percobaanm para ahli Psikologi dapat menggambarkan bagaimana proses tersebut berlangsung. Ahli Psikologi konstruktivis berpendapat bahwa proses pemerolehan pengetahuan adalah melalui penstrukturan kembali struktur kognitif yang telah dimiliki agar bersesuaian dengan 
pengetahuan yang akan diperoleh sehingga pengetahuan itu dapat diadaptasi.

Proses belajar mengajar dapat berjalan dengan baik bila terdapat metode atau cara mengajar yang baik pula. Menurut hamalik (2003:2) metode mengajar merupakan suata tindakan, teknik, upaya, prosedur yang dilakukan dalam proses belajar mengajar. Pengertian lainnya, metode mengajar adalah teknik yang digunakan guru untuk membantu penyampaian materi ajar/bahan ajar kepada peserta didik supaya materi ajar dapat diterima, ditangkap, dipahami, serta digunakan oleh peserta didik dengan benar.

Ada berbagai metode yang dapat digunakan guru dalam kegiatan pembelajaran, diantaranya: ceramah bervariasi, tanya jawab, diskusi, pemberian tugas, bermain peran, karyawisata, inquiry, kerja kelompok, demonstrasi. Dari sekian banyak metode itu tidak akan mungkin semuanya akan digunakan. Namun yang terpenting adalah penggunaan metode harus dikaitkan dengan situasi dan tujuan belajar yang hendak dicapai dan ditekankan pada keaktifan peserta didik dalam membangun pengetahuan.

Metode pembelajaran yang dapat diterapkan dalam pembelajaran yang menggunakan pendekatan konstruktivisme adalah metode inkuiri. Metode inkuiri ditandai dengan kegiatan tanya jawab, penyelidikan, dan komunitas belajar. Dalam pembelajaran yang berbasis inquiry, kegiatan bertanya merupakan bagian yang sangat penting untuk menggali informasi, 
mengonfirmasikan hal-hal yang sudah diketahui, serta mengarahkan perhatian pada hal-hal yang belum diketahuinya.

Adapun penyelidikan diperlukan untuk menggali informasi, pengetahuan, keterampilan yang akan diperoleh peserta didik dengan cara menemukan pengetahuan dan pemahaman mereka sendiri bukan dengan hasil mengingat-ngat. Tentu saja, proses pemanggilam memori akan pengetahuan yang lampau akan tetap digunakan. Namun, yang ditekankan disini adalah guru senantiasa berusaha untuk merancang kegiatan pembelajaran yang bertujuan menemukan pengetahuan sendiri terkait materi pembelajaran.

Melihat penjelasan diatas, metode inkuiri bersifat student centered (berpusat pada siswa). kegiatan pembelajaran, didominasi dengan kegiatan penemuan, praktek, percobaan-percobaan untuk dapat menemukan jawaban dari pertanyaan rumusan yang dibuat pada awal pembelajaran sehingga siswa dapat lebih memahami dan mengingat pembelajaran dengan jangka waktu yang lama dan lebih awet.

\section{SIMPULAN}

1. Menurut teori konstruktivistik, satu prinsip yang paling penting dalam psikologi pendidikan adalah bahwa guru tidak hanya sekedar memberikan pengetahuan kepada peserta didik.

2. Peserta didik harus membangun sendiri pengetahuan di dalam benaknya. 
3. Ciri-ciri pembelajaran konstruktivis, antara lain: a) pengetahuan dibangun berdasarkan pengalaman atau pengetahuan yang sudah ada sebelumnya; b) memanfaatkan berbagai media termasuk komunikasi lisan dan tertulis sehingga pembelajaran menjadi lebih efektif; c) memberikan beberapa alternatif dalam mendapatkan pengalaman belajar, tugas-tugas yang berbeda, memberi kesempatan yang berbeda dalam menyelesaikan permasalahan; dan d) bekerja sama dengan sekitar.

4. Dalam pembelajaran IPS, pendekatan konstruktivisme dapat dilakukan pada semua topik dan poko bahasan.

\section{KERJAKAN AKU!}

Apakah semua materi ajar IPS SD dapat disampaikan dengan menggunakan pendekatan konstruktivisme? Jelaskan alasannya!

Pilihlah satu materi ajar IPS SD dan buatlah rancangan sederhana penerapan pendekatan konstruktivisme didalamnya! 


\section{DAFTARRUJUKAN}

Budiningsih, A.C. (2005). Belajar dan Pembelajaran. Jakarta: Rineka Cipta

Hamalik, O. (2003). Proses Belajar Mengajar. Jakarta: Sinar Grafika Piaget, J. 1963. The Psychology of Intelligence. New York: Routledge

Poedjiadi, A. (1997). Memperkenalkan Pendidikan Sains Teknologi dan Masyarakat. Bandung: Program Pascasarjana IKIP Bandung

Roestiyah, N.K. (2008). Strategi Belajar Mengajar. Jakarta: Rineka Cipta

Sanjaya, W. (2007). Kurikulum dan Pembelajaran. Jakarta: Kencana Prenada Media Group

Siroj, R.A. (2004). Pemerolehan Pengetahuan Menurut Pandangan Konstruktivistik. (online). Tersedia:

http://www.depdiknas.go.id/jurnal/43/rusdy-a-sirij.htm 


\section{BAB IV}

\section{PENDEKATAN INKUIRI DALAM PEMBELAJARAN ILMU PENGETAHUAN SOSIAL}

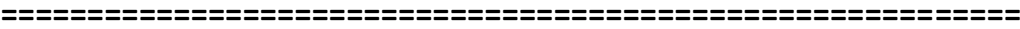
TUJUAN PEMBELAJARAN

- Mahasiswa mampu menuliskan pengertian pendekatan pembelajaran inkuiri

- Mahasiswa mampu menuliskan ciri-ciri pendekatan pembelajaran inkuiri

- Mahasiswa mampu mensimulasikan pendekatan inkuiri dalam pembelajaran IPS SD

\section{a. Pengertian Pendekatan Pembelajaran Inkuiri}

Inkuiri atau penemuan adalah proses mental dimana peserta didik mengasimilasi suatu konsep atau prinsip, misalnya mengamati, menggolongkan, membuat dugaan, menjelaskan, mengukur, dan membuat kesimpulan dan sebagainya (Oemar Hamalik, 2001:219). Penemuan yang dilakukan tentu saja bukan penemuan yang sesungguhnya, sebab apa yang ditemukan itu sebenarnya sudah ditemukan orang lain. Jadi penemuan disini adalah penemuan pura-pura atau penemuan peserta didik yang bersangkutan saja.

Inkuiri berarti pertanyaan, pemeriksaan, atau penyelidikan. Inkuiri sebagai suatu proses umum yang dilakukan manusia untuk mencari atau memahami informasi. Pendekatan inkuiri berarti suatu rangkaian 
kegiatan belajar yang melibatkan secara maksimal seluruh kemampuan peserta didik untuk mencari dan menyelidiki secara sistematis, kritis, logis, analitis sehingga mereka dapat merumuskan sendiri penemuannya dengan penuh percaya diri.

$$
\text { Savage dan Armstrong }
$$

mengembangkan pendekatan inkuiri sebagai salah satu bagian dari upaya guru dalam membantu para peserta didik sekolah dasar untuk meningkatkan keterampilan berpikir. Pendekatan pembelajaran inkuiri merupakan model pembelajaran yang berorientasi kepada pengalaman peserta didik. Melalui pembelajaran inkuiri, maka guru akan mudah mengembangkan diri sebagai peserta didik sebagai tanggung jawabnya. Selain itu, dengan pembelajaran inkuiri, akan memotivasi peserta didik untuk aktif mencari dan mendapatkan pengetahuan.

Adapun menurut Jarolimek

(1976:72) pendekatan pembelajaran inkuiri adalah "the major goal of inquiry-oriented teaching is to develop in pupils those attitudes and skill that will enable them to be independent problem solver. This involves more than simply knowing where to go to get needed information. It requires an attitude of curiosity, the ability to analyze a problem, the ability to make and test hunches and the ability to use information in validiting conclusions". Jadi, menurut Jarolimek, inkuiri tidak hanya terbatas kepada pertanyaan atau pemeriksaan, melainkan meliputi pula proses penelitian, keingintahuan, analisis sampai kepada 
penarikan kesimpulan tentang hal-hal yang diperiksa atau diteliti. Dalam rangkan pendidikan IPS, pendekatan inkuiri ini diarahkan kepada kemampuan anak didik berpikir kritis dan menjadi orang yang secara bebas dapat memecahkan sendiri masalah yang dihadapinya.

Menurut Gulo dalam Trianto (2007:135) sasaran utama pembelajaran inkuiri adalah: 1) keterlibatan peserta didik secara maksilam dalam proses kegiatan belajar; 2) keterarahan kegiatan secara logis dan sistematis pada tujuan pembelajaran; dan 3) mengembangkan sikap percaya pada diri peserta didik tentang apa yang ditentukan pada proses inkuiri.

Dari semua konsep tentang pendekatan inkuiri diatas, maka yang dimaksud dengan pendekatan pembelajaran inkuiri adalah serangkaian proses pembelajaran yang berpusat pada peserta didik dengan penekanannya pada kemampuan berpikir kritis, analitik, mencari, menemukan, dan mengolah informasi-informasi dan pengetahuan sendiri oleh persera didik, yang berguna untuk mencerahkan masalah-masalah yang dihadapi dalam proses pembelajaran.

\section{b. Ciri-ciri Pendekatan Pembelajaran Inkuiri}

Dari definisi yang dikemukakan di atas, dapat dipahami bahwa pembelajaran inkuiri lebih ditekankan pada pengembangan kemampuan pemecahan masalah yang terbatas pada disiplin ilmu, serta berlandaskan pada masalah yang ada pada disiplin ilmu. Lebih 
lanjut, model pembelajaran inkuiri ini memiliki ciriciri sebagai berikut:

1. Sangat memperhatikan proses pengumpulan data dan pengujian hipotesis;

2. Proses pengumpulan data dilakukan secara sistematis dan berdasarkan tradisi keilmuan disiplin tertentu (walaupun perlu adanya penyerderhanaan proses sehingga sesuai dengan kemampuan peserta didik);

3. Adanya proses pengolahan data dan pengujian hipotesis (yang merupakan suatu keharusan dalam inkuiri dan bukan alternatif seperti pemecahan masalah);

4. Pembelajaran inkuiri maupun pemecahan masalah mempunyai keunggulan yang sama, yaitu kemampuan berpikir aplikasi, analisis, sintesis, dan evaluasi; dan

5. Langkah yang dilakukan dalam inkuiri terdiri atas: perumusan masalah, pengembangan hipotesis, pengumpulan data, pengolahan data, pengujian hipotesis, dan penarikan kesimpulan.

Dahlan (1990:169) menyatakan bahwa ada tiga ciri pokok dalam pendekatan pembelajaran inkuiri, yaitu:

1. Adanya aspek-aspek sosial dalam kelas yang dapat menumbuhkan terciptanya suasanan diskusi kelas,

2. Adanya penetapan hipotesis sebagai arah dalam pemecahan masalah, dan

3. Menggunakan fakta sebagai pengujian hipotesis. 
Menurut Sanjaya (2007: 194-195) ada beberapa hal yang menjadi ciri utama dari pembelajaran inkuiri, yaitu:

1. Menekankan pada aktivitas peserta didik secara maksimal untuk mencari dan menemukan,

2. Seluruh aktivitas yang dilakukan peserta didik diarahkan untuk mencari dan menemukan jawaban sendiri dari suatu yang dipertanyakan, dan

3. Bertujuan untuk mengembangkan kemampuan berpikir secara sistematis dan kritis, atau mengembangkan kemampuan intelektual sebagai bagian dari proses mental.

Ketika proses pembelajaran yang menggunakan pendekatan inkuiri berlangsung guru hendaknya dapat berperan sebagai pembimbing. Dalam membimbing peserta didik, guru bukanlah sebagai pemberi perintah, akan tetapi gurus ebagai motivator, fasilitator, dan reflektor.

\section{c. Implementasi Pendekatan Inkuiri dalam Pembelajaran IPS SD}

Pada umumnya pendekatan pembelajaran inkuiri dilaksanakan dengan mengikuti langkah-langkah sebagai berikut:

\section{Orientasi}

Langkah orientasi merupakan langkah untuk membina suasana atau iklim pembelajaran yang responsif. Guru berusaha untuk mengondisikan pesera didik agar siap melaksanakan proses pembelajaran. Langkah ini sangat penting sebab 
keberhasilan pendekatan pembelajaran ini sangat tergantung pada kemauan peserta didik untuk beraktivitas menggunakan kemampuannya memecahkan masalah. Beberapa hal yang dapat dilakukan dalam tahap orientasi ini adalah: a) menjelaskan topik, tujuan, dan hasil belajar yang diharapkan dapat dicapai oleh peserta didik; b) menjelaskan pokok-pokok kegiatan yang harus dilakukan peserta didik untuk mencapai tujuan. Pada tahap ini dijelaskan langkah-langkah inkuiri serta tujuan setiap langkah, mulai dari langkah merumuskan masalah sampai langkah merumuskan kesimpulan; dan c) menjelaskan pentingnya topik dan kegiatan belajar. Hal ini dilakukan dalam rangkan memberikan motivasi belajar bagi peserta didik.

\section{Perumusan Masalah}

Dalam pelaksanaan penelitian, termasuk juga pembelajaran inkuiri, perumusan masalah merupakan sesuatu yang sangat penting sebelum para ahli memulai riset mengenai berbagai masalah, mereka harus dengan jelas merumuskan pertanyaan yang harus dijawab. Pertanyaan ilmiah yang diajukan haruslah lengkap, tepat, dan dapat diuji. Membentuk peserta didik untuk mengidentifikasi dan merumuskan pertanyaan yang tepat, eksplisit, dan dapat diukur merupakan salah satu tugas guru yang paling menantang dalam kelas yang berorientasi pada inkuiri. 
Kemampuan untuk menanyakan pertanyaan yang baik adalah keahlian yang harus dikembangkan, dapat diajarkan secara sistematis, dan dapat dimulai dari taman kanak-kanak. Pada tahap ini, peserta didik dilatih untuk merumuskan pertanyaan dalam kajian IPS. Mereka bisa merumuskan permasalahan antara lain: latar belakang suatu peristiwa terjadi, faktor-faktor penyebab tumbuh atau hancurnya suatu peradaban, dan lain-lain.

Beberapa hal penting yang harus diperhatikan dalam merumuskan masalah:

a) Masalah hendaknya dirumuskan sendiri oleh peserta didik, dengan demikian mereka akan memiliki motivasi belajar yang tinggi, karena mereka dilibatkan dalam perumusan masalah yang akan dikaji. Guru hanya memberikan topik yang akan dipejari. Adapun bagaimana merumusakan masalah yang sesuai dengan topik tersebut diserahkan kepada peserta didik.

b) Masalah yang dikaji berupa yang mengandung teka-teki yang jawabannya pasti.

c) Sebelum masalah dikaji lebih jauh dalam proses inkuiri, guru harus yakin bahwa peserta didik sudah memiliki pemahaman tentang konsep-konsep yang ada dalam rumusan masalah.

\section{Mengajukan Hipotesis}


Hipotesis merupakan jawaban sementara dari suatu permasalahan yang sedang dikaji. Karena itu, hipotesis perlu diuji kebenarannya. Untuk itu guru harus mengajukan berbagai pertanyaan yang dapat mendorong peserta didik untuk dapat merumuskan jawaban sementara atas permasalahan yang dikaji. Perkiraan sebagai hipotesis harus memiliki landasan berpikir yang kukuh, sehingga hipotesis yang dikemukakan bersifat rasional, dan logis.

Perumusan hipotesis akan efektif dilakukan peserta didik, jika permasalahan yang diajukan didasarkan pada pengetahuan masa lampau dan teori-teori yang ada. Hipotesis yang baik bukan merupakan rumusan kosong dan terkaan-terkaan yang bodoh, tetapi merupakan jawaban melalui proses berpikir dari pengetahuan yang sudah mereka miliki.

\section{Mengumpulkan Data}

Mengumpulkan data berarti aktivitas menjaring informasi yang dibutuhkan untuk menguji hipotesis yang diajukan. Dengan strategi belajar ini, pengumpulan data merupakan proses mentak yang sangat penting dalam pengembangan intelektual. Proses ini membutuhkan motivasi yang kuat untuk belajar, ketekunan, dan kemampuan menggunakan potensi berpikirnya. Oleh sebab itu, tugas dan peran guru dalam tahap ini harus mengajukan pertanyaan-pertanyaan yang 
dapat mendorong pesera didik untuk mencari informasi yang dibutuhkan. Bila peserta didiknya tidak apresiatif terhadap pesemasalahan yang ada, guru harus memberikan motivasi kepada peserta didik untuk belajar melalui penyuguhan berbagai jenis pertanyaan secara merata ke seluruh peserta didik sehingga mereka terdorong untuk berpikir.

Dalam praktiknya, pengumpulan data ini dapat diperoleh melalui cara-cara sebagai berikut:

a) Mengundang ahli sejarah dari universitas untuk menjelaskan bagaimana mereka memperoleh informasi untuk menulis buku;

b) Melihat buku harian atau jurnal yang ditulis di waktu lampau yang dapat memberi tahu seperti apa kehidupan pada jaman itu;

c) Pergi ke perpustakaan sekolah dan perpustakaan umum; atau

d) Mencari film atau potongan film atau gambar yang berhubungan dengan permasalahan.

Melalui pengumpulan data, peserta didik akan belajar bagaimana menemukan dan menentukan sumber yang valid. Pada tahap ini peserta didik akan belajar bagaimana mengkritik berbagai sumber, baik berupa buku teks, film dokumenter, ataupun mengakses dari internet. Kegiatan pengumpulan dan penyelidikan sumbersumber dan informasi yang berhubungan dengan permasalahan yang sedang dibahas, merupakan bagian dari prosedur penelitian dalam pembelajaran inkuiri. 


\section{Menguji Hipotesis}

Menguji hipotesis adalah proses menemukan jawaban yang dianggap diterima sesuai dengan data atau informasi yang diperoleh. Dalam menguji hipotesis, yang penting adalah mencari tingkat keyakinan peserta didik atas jawaban yang diberikan. Menguji hipotesis juga berarti mengembangkan kemampuan berpikir rasional dan logis. Artinya kebenaran jawaban yang diberikan bukan hanya berdasarkan argumentasi, akan tetapi harus didukung oleh data yang ditemukan dan dapat dipertanggungjawabkan.

Saat peserta didik mengevaluasi informasi, mereka harus memeriksa dengan teliti sumbernya, metode yang digunakan untuk mengumpulkan informasi tersebut, dan mencoba mengidentifikasi kelemahan dan keterbatasan informasi. Peserta didik dapat menemukan dokumen, artefak, karya seni, dan jenis bukti lainnya yang asalnya tidak diketahui. Mereka harus mencoba untuk merumuskan hipotesis yang berguna mengenai asal informasi tersebut, menghubungkannya dengan data yang ada, dan menentukan apakah data itu penting untuk pengujian hipotesis mereka.

\section{Merumuskan Kesimpulan}

Penarikan kesimpulan dilakukan ketika hipotesis telah diuji leberannya. Peserta didik 
dapat mengungkapkan apakah hipotesisnya benar atau tidak, setelah itu baru merumuskan generalisasi terhadap permasalahan yang dibahas.

Merumuskan kesimpulan berupa proses pendeskripsian temuan yang diperoleh berdasarkan hasil penemuan hipotesis. Agar kesimpulan yang dirumuskan terfokus pada masalah yang hendak dipecahkan, maka sebaiknya guru menunjukkan kepada pesera didik data mana yang relevan.

\section{SIMPULAN}

1. Pembelajaran inkuiri merupakan kegiatan pembelajaran yang melibatkan secara maksimal seluruh kemampuan peserta didik untuk mencari dan menyelidiki sesuatu (benda, manusia atau peristiwa) secara sistematis, kritis, logis, analitis sehingga mereka dapat merumuskan sendiri penemuannya dengan penuh percaya diri.

2. Pembelajaran inkuiri menekankan kepada proses mencari dan menemukan.

3. Langkah-langkah pembelajaran inkuiri: merumuskan masalah, membangun hipotesis, menguji jawaban tentatif (mengamati/observasi), menganalisis dan menyajikan hasil dalam tulisan/laporan/gambar, menerapkan kesimpulan serta generalisasi, dan menyajikan hasil karya.

4. Dengan penggunaan pendekatan inkuiri dalam pembelajaran IPS, peserta didik dibiasakan untuk mencari pemecahan atas masalah yang mereka alami. 


\section{KERJAKAN AKU!}

Bagaimana karakteristik materi ajar IPS SD yang dapat diimplementasikan dengan pemnbelajaran inkuiri? Jelaskan!

Pilihlah satu materi ajar IPS SD dan buatlah rancangan sederhana penerapan pembelajaran inkuiri didalamnya! 


\section{DAFTARRUJUKAN}

Dahlan, M.D. (1990). Model-model Mengajar. Bandung: CV Diponegoro

Hamalik, O. (2001). Belajar Mengajar. Jakarta : Bumi Aksara Jarolimek, J. \& Forste, C.D. (1976) . Teaching and Learning in The Elementary School. London: Mc. Millan Pub.Co.Inc

Sanjaya, W. (2007). Kurikulum dan Pembelajaran. Jakarta: Kencana Prenada Media Group

Trianto. (2007). Model-model Pembelajaran Inovatif Berorientasi Kontekstualistik. Surabaya: Prestasi Pustaka 
BAB V

PENGGUNAAN MODEL PEMBELAJARAN KOOPERATIF DALAM PENDIDIKAN IPS

\section{TUJUAN PEMBELAJARAN}

- Mahasiswa mampu memahami pengertian model pembelajaran kooperatif

- Mahasiswa mampu menuliskan ciri-ciri model pembelajaran kooperatif

- Mahasiswa mampu mensimulasikan model pembelajaran kooperatif beserta teknik-tekniknya dalam pembelajaran IPS SD

\section{a. Pengertian Model Pembelajaran Kooperatif}

Upaya guru dalam mengajar peserta didik adalah bagian yang sangat penting dalam mencapai keberhasilan tujuan pembelajaran yang direncanakan. Oleh sebab itu pilihan berbagai metode, strategi, pendekatan dan teknik pembelajaran adalah hal utama.

Model pembelajaran kooperatif adalah model pembelajaran yang mengutamakan eksistensi kelompok. Setiap peserta didik dalam kelompok memiliki tingkat kemampuan yang berbeda (tinggi, sedang dan rendah) dan jika mungkin anggota kelompok berasal dari ras, budaya, suku yang berbeda dan memperhatikan kesetaraan gender. Model pembelajaran kooperatif mengutamakan kolaborasi dalam memecahkan masalah untuk menerapkan pengetahuan dan keterampilan untuk mencapai tujuan pembelajaran. 
Menurut Sanjaya (2006: 240), model pembelajaran kooperatif merupakan model pembelajaran dengan menggunakan sistem pengelompokkan yang terdiri dari empat hingga enam orang dengan latar belakang kemampuan akademik, jenis kelamin, ras, atau suku yang berbeda (heterogen). Kebanyakan pembelajaran yang menggunakan model kooperatif dapat memiliki ciri-ciri sebagai berikut: 1) peserta didik bekerja dalam kelompok secara kooperatif untuk memutuskan materi belajarnya; 2) kelompok dibentuk dari peserta didik yang memiliki kemampuan tinggi, sedang, dan rendah; 3) bila mungkin, anggota kelompok berasal dari ras, budaya, suku, jenis kelamin berbeda-beda; dan 4) penghargaan lebih berorientasi pada kelompok ketimbang individu.

Sementara Riyanto (2009: 271) mendefinisikan pembelajaran kooperatif sebagai model pembelajaran yang dirancang untuk membelajarkan kecakapan akademik, sekaligus keterampilan sosial termasuk keterampilan interpersonal.

Dengan demikian, dapat disimpulkan bahwa pembelajaran kooperatif adalah model pembelajaran yang dilaukan dengan cara mengelompokkan peserta didik ke dalam kelompok-kelompok kecil yang anggotanya terdiri dari berbagai unsur peserta didik yang heterogen untuk bekerja sama secara terarah dalam sebuah tim untuk menyelesaikan masalah, tugas, atau mengerjakan sesuatu dalam mencapai tujuan bersama. 


\section{b. Ciri-ciri Model Pembelajaran Kooperatif}

Nurhadi (2004) memaparkan beberapa ciri-ciri pembelajaran kooperatif yaitu sebagai berikut.

1. Setiap anggota memiliki peran;

2. Terjadi hubungan interaksi langsung di antara peserta didik;

3. Setiap anggota kelompok bertanggung jawab atas belajarnya dan juga teman-teman sekelompoknya;

4. Guru membantu mengembangkan keterampilanketerampilan interpersonal kelompok, dan

5. Guru hanya berinteraksi dengan kelompok saat diperlukan.

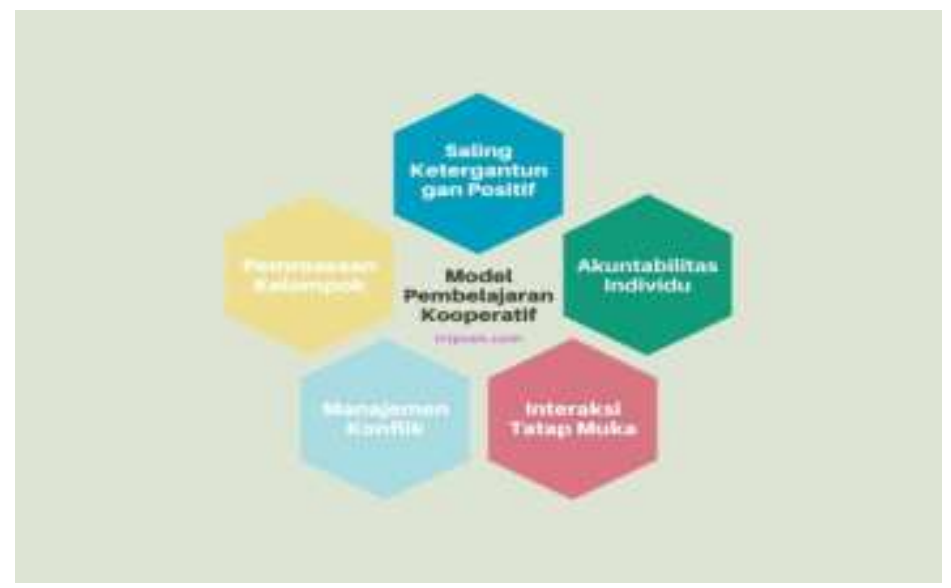

Gambar 5.1. CIri Model Pembelajaran Kooperatif

Pakar pendidikan Lie, 2002 menjelaskan bahwa terdapat beberapa komponen dasar yang menjadi ciri pembelajaran kooperatif, yakni:

1. Rasa saling membutuhkan 
Guru menyampaikan pada peserta didik untuk saling mengenal, saling berinteraksi secara aktif dengan rekannya sehingga memunculkan rasa saling ketergantungan dan saling membutuhkan namun dalam hal positif. Contoh: peserta didik saling membantu dan memberi perannya untuk dapat mengerjakan tugas tepat waktu

2. Rasa tanggung jawab individu akan muncul

Tujuan dari pembelajaran kooperatif salah satunya adalah supaya peserta didik dapat memahami sejauh mana kemampuan dirinya dalam menangkap materi pelajaran. Selanjutnya, nilai yang diperoleh oleh mereka disampaikan oleh guru sehingga mereka dapat mengetahui langsung kemamampuan mereka dan segera menyelesaikan permasalahan bila ada kesulitan dalam pemahaman.

Selanjutnya, seluruh hasil belajar yang didapat akan dirata-rata dan mendapatkan hasil akhir yang merupakan titik temu kemampuan masing-masing peserta didik.

3. Interaksi tatap muka

Metode tatap muka akan membuat peserta didik bisa bersosialisasi secara langsung. Ini membuat ruangan kelas menjadi lebih interaktif dan bisa memicu munculnya diskusi.

4. Keterampilan sosial

Keterampilan sosial merupakan hal penting bagi peserta didik. Bila keterampilan sosial mereka tinggi, tentu saja akan menciptakan kondisi yang bersahabat dan meningkatkan kekompakan antar peserta didik. 
Model pembelajaran ini juga akan efektif bagi peserta didik yang memiliki kekurangan kepercayaan diri atau minder. Mengapa? Karena model ini menjalin hubungan antar peserta didik dengan rata. Guru dapat mengingatkan peserta didik yang tidak membantu kelompoknya.

Dengan memanfaatkan model ini peserta didik bisa berpartisipasi dan terlibat secara aktif dalam pembelajaran. Berikut adalah langkah-langkah atau sintaks dari model pembelajaran kooperatif:

1. Guru menyampaikan informasi tentang visi dan misi pembelajaran untuk menyiapkan peserta didik.

2. Menyampaikan penjelasan ringkas dari bahan ajar yang akan dilakukan.

3. Mengutarakan informasi tentang perumusan grup dan cara pembelajaran berlangsung agar bisa dilakukan dengan tepat.

4. Menyediakan data dan pengetahuan untuk proses belajar peserta didik dalam menemukan solusi dari tugas dan diskusi.

5. Membuat semacam tes kepada peserta didik untuk menguji kemampuan yang telah didapat dari pembelajaran individu dan kelompok.

6. Lakukan evaluasi setelah proses pembelajaran dan apresiasi setiap usaha peserta didik dalam menemukan solusi dari tugas yang dikerjakan.

\section{c. Implementasi Model Pembelajaran Kooperatif}

Model pembelajaran kooperatif merupakan teknikteknik kelas praktis yang dapat digunakan guru setiap 
hari untuk membantu peserta didik belajar setiap mata pelajaran, mulai dari keterampilan-keterampilan dasar sampai pemecahan masalah yang kompleks. Dalam model pembelajaran kooperatif, peserta didik bekerja dalam kelompok-kelompok kecil saling membantu belajar satu sama lainnya. Kelompok-kelompok tersebut beranggotakan peserta didik dengan hasil belajar tinggi, rata-rata, dan rendah; laki-laki dan perempuan; peserta didik dengan latar belakang suku berbeda yang ada di kelas; dan peserta didik penyancang cacat bila ada. Kelompok beranggotakan heterogen ini tinggal bersama selama beberapa minggu, sampai mereka dapat belajar bekerja sama dengan baik sebagai sebuah tim.

Model pembelajaran kooperatif menciptakan sebuah revolusi pembelajaran di dalam kelas. Tidak ada lagi sebuah kelas yang sunyi selama proses pembelajaran; sekarang kita tahu bahwa pembelajaran yang terbaik tercapai di tengah-tengah percakapan di atanra peserta didik. Sedang terjadi kecenderungan dimana-mana, bahwa para guru di seluruh dunia mengubah deretan tempat duduk peserta didik yang telah mereka duduki sekian lama, dan dengan menciptakan suatu lingkungan kelas baru tempat peserta didik secara rutin dapat saling membantu satu sama lain guna menuntaskan bahan ajar akademiknya.

Secara umum, langkah-langkah yang harus dilakukan guru dalam melaksanakan model pembelajaran kooperatif, yaitu sebagai berikut:

1. Guru merancang Rencana Perencanaan Pembelajaran (RPP) dengan menetapkan tujuan yang akan dicapai, 
baik ranah kognitif, afektif, atau sikap, maupun psikomotorik atau keterampilan sosial yang dapat dikembangkan oleh peserta didik baik secara individu maupun kelompok;

2. Saat menyampaikan materi, guru hanya menyampaikan pokok-pokok materinya saja, karena pendalaman materi akan dibahas dan dilakukan oleh peserta didik melalui belajar kelompok. Pada saat belajar kelompok guru mulai melakukan monitoring dan mengobservasi kegiatan belajar berdasarkan lembar observasi yang telah disiapkan sebelumnya. Lembar observasi ini akan digunakan untuk mengamati kegiatan peserta didik dalam belajar secara bersama-sama dalam kelompok kecil;

3. Pada saat kegiatan diskusi kelompok berlangsung, guru harus membimbing dan mengarahkan peserta didik, baik secara individual maupun kelompok agar selama diskusi berlangsung tidak keluar dari jalur yang telah direncanakan. Guru mengarahkan dan membimbing peserta didik baik secara individual maupun kelompok, baik dalam memahami materi maupun mengenai sikap dan perilaku selama kegiatan belajarnya dan melatih keterampilan sikap dan perilaku selama kegiatan belajarnya dan melatih keterampilan sosial secara optimal, dan melatih peserta didik untuk dapat hidup bermasyarakat.

4. Guru bertindak sebagai moderator ketika masingmasing kelompok mempresentasikan hasil kerjanya dalam diskusi kelas. Hal ini dimaksudkan untuk mengarahkan dan mengoreksi pengertian dan 
pemahaman peserta didik terhadap materi atau hasil kerja yang telah ditampilkannya. Pada tahap ini, guru memberikan kesempatan kepada peserta didik dari masing-masing kelompok mempresentasikan hasil kerjanya dan guru memoderatori antara peserta didik penanya dan presentator. Pada akhir pembelajaran, guru mengajak peserta didik untuk melakukan refleksi diri terhadap proses pembelajaran dengan tujuan untuk memperbaiki kelemahan-kelemahan selama pembelajaran. Guru juga memberikan penekanan terhadap nilai, sikap, dan perilaku sosial yang harus dikembangkan dan dilatih peserta didik.

\section{d. Teknik Model Pembelajaran Kooperatif}

Beberapa macam teknik model pembelajaran kooperatif yang dapat digunakan dalam pembelajaran menurut Lie (2002: 54), antara lain:

1. Teknik mencari pasangan (make a match), yaitu teknik yang dikembangkan oleh Loma Curran (1994). Salah satu keunggulan teknik ini adalah peserta didik mencari pasangan sambil belajar mengenai suatu konsep atau topik dalam suasana yang menyenangkan. Teknik ini bisa digunakan dalam semua mata pelajaran dan untuk semua tingkatan usia.

2. Bertukar pasangan, yaitu memberi kesempatan pada sisswa untuk bekerja sama dengan orang lain. Pasangan bisa ditunjuk oleh guru atau berdasarkan teknik mencari pasangan.

3. Berpikir berpasangan berempat (think-pair-share), yaitu teknik yang dikembangkan oleh Frank Lyiran 
(think-pair-share) dan Spenser Kagan (think-pairsquare). Teknik ini memberi peserta didik kesempatan untuk bekerja sendiri serta bekerja sama dengan orang lain.

4. Berkirim salam dan soal, teknik ini memberi kesempatan kepada peserta didik untuk melatih pengetahuan dan keterampilan mereka. Peserta didik membuat pertanyaan sendiri, sehingga akan merasa terdorong untuk belajar dan menjawab pertanyaan yang dibuat oleh teman sekelasnya.

5. Kepala bernomor (numbered heads), teknik ini dikembangkan oleh Spencer Kagan (1992). Teknik ini memberi kesempatan kepada peserta didik untuk saling membagikan ide-ide dan pertimbangan jawaban yang paling tepat. Selain itu teknik ini mendorong peserta didik untuk meningkatkan semangat kerjasama mereka.

6. Kepala bernomor terstruktur, teknik ini modifikasi dari teknik kepala bernomor yang dipakai Spencer kagan. Dengan teknik ini, peserta didik bisa belajar melaksanakan tanggung jawab pribadinya dan saling keterkaitan dengan teman-teman kelompoknya.

7. Dua tinggal dua tamu (two stay two stray). Teknik ini dikembangkan oleh Spencer Kagan (1992) dan bisa digunakan dengan teknik kepala bernomor. Teknik ini memberi kesempatan kepada peserta didik untuk membagikan hasil informasi dengan kelompok lain.

8. Keliling kelompok, dalam teknik ini masing-masing anggota kelompok mendapatkan kesempatan untuk 
memberikan kontribusi mereka dan mendengarkan pandangan dan pemikiran anggota yang lain.

9. Lingkaran kecil lingkaran besar (inside-outside circle), teknik ini untuk memberikan kesempatan kepada peserta didik agar saling berbagi informasi pada saat yang bersamaan.

10. Tari bambu, teknik ini merupakan modifikasi lingkaran kecil lingkaran besar, karena keterbatasan ruang kelas.

11. Jigsaw, yang dikembangkan oleh Aronson, dkk. Dalam teknik ini, guru memperhatikan skemata atau latar belakang pengalaman peserta didik dan membantu peserta didik mengaktifkan skemata ini agar bahan pelajaran menjadi lebih bermakna. Selain itu, peserta didik bekerja sama dengan sesama peserta didik lain dalam suasana gotong royong dan mempunyai banyak kesempatan untuk mengolah informasi dan meningkatkan keterampilan berkomunikasi.

12. Bercerita berpasangan (paired storry telling), dikembangkan sebagai pendekaran interaktif antara peserta didik, pengajar, dan bahan pengajaran.

Demikian beberapa teknik yang bisa digunakan dalam proses pembelajaran yang menggunakan model pembelajaran kooperatif, namun tidak harus semua teknik-teknik tersebut dipraktikkan seluruhnya di depan kelas, namun guru harus mampu memilih dan menentukan teknik yang sesuai dengan situasi kelas serta materi pelajaran yang akan diberikan kepada peserta didik. 


\section{SIMPULAN}

1. Model Pembelajaran Kooperatif merupakan model pembelajaran dengan kelompok kecil peserta didik dan membangun kondisi belajar yang kondusif.

2. Model pembelajaran kooperatif mengajarkan peserta didik untuk mengembangkan keterampilan sosial, menerima perbedaan dan keragaman, serta meningkatkan hasil belajar akademik.

3. Beberapa teknik dalam model pembelajaran kooperatif, diantaranya: jigsaw, think pair shared, numbered heads, two stay two stray, paired storry telling, tari bambu, lingkaran kecil lingkaran besar, dan lainnya.

4. Langkah-langkah model pembelajaran kooperatif, diantaranya: a) menyampaikan tujuan dan mempersiaplan peserta didik; b) menyajikan informasi; c) mengorganisir peserta didik ke dalam tim-tim belajar (heterogen); d) membentuk kerja tim dan belajar; e) mengevaluasi; dan f) memberikan pengakuan atau penghargaan. 


\section{KERJAKAN AKU!}

Begitu banyak macam dari model pembelajaran kooperatif. Menurut Anda, teknik manakah yang sesuai dengan jenjang kelas rendah dan kelas tinggi SD? Jelaskan alasannya!

\section{DAFTARRUJUKAN}

Lie, A. (2002). Cooperative Learning; Mempraktekkan Cooperative Learning di Ruang-ruang Kelas. Jakarta: Grasindo

Nurhadi. (2004). Pembelajaran Kontekstual (Contextual Teaching and Learning/CTL) dan Penerapannya Dalam KBK. Malang: Universitas Negeri Malang.

Sanjaya, W. (2006). Strategi Pembelajaran Berbasis Standar Proses Pendidikan. Bandung: Alfabeta 


\section{BAB VI \\ PENDEKATAN SAINS TEKNOLOGI DAN MASYARAKAT DALAM PENGEMBANGAN PEMBELAJARAN IPS SD}

\section{TUJUAN PEMBELAJARAN}

- Mahasiswa mampu memahami pengertian pendekatan saint teknologi masyarakat

- Mahasiswa mampu memahami tujuan pendekatan sains teknologi masyarakat

- Mahasiswa mampu mengidentifikasi karakteristik dan ciri-ciri pendekatan sains teknologi masyarakat

- Mahasiswa mampu mensimulasikan pendekatan sains teknologi masyarakat dalam pembelajaran IPS SD

\section{a. Pengertian Pendekatan Sains Teknologi dan Masyarakat}

Sains teknologi dan masyarakat merupakan istilah yang diterjemahkan dari bahasa Inggris, Science Technology Society, yang pertama kali dikemukakan oleh John Ziman dalam karyanya yang berjudul "Teaching and Learning about Science and Society". Pembelajaran Science Technology Society berarti pembelajaran dengan menggunakan teknologi sebagai penghubung antara sains dan masyarakat. Di Indonesia, science technology society diterjemahkan menjadi sains teknologi masyarakat (STM).

Di Indonesia, pendekatan STM ini mulai diperkenalkan di tahun 1990. Di negara pengembangnya, yaitu Inggris dan Amerika, pendekatan STM atau STS ini 
telah banyak digunakan dalam pembelajaran sejak tahun 1970-an.

Pendekatan STM (Sains Teknologi Masyarakat) adalah suatu usaha untuk menyajikan sains (IPA) melalui pemanfaatan masalah-masalah dalam kehidupan seharihari. Pendekatan sains teknologi dan masyarakat melibatkan peserta didik dalam penentuan tujuan pembelajaran, prosedur pelaksanaan pembelajaran, pencarian informasi bahan pembelajaran dan bahkan pada evaluasi belajar. Tujuan utama pendekatan STM yaitu agar dihasilkan peserta didik-peserta didik yang memiliki bekal ilmu dan pengetahuan agar nantinya mampu mengambil keputusan-keputusan terkait masalah-masalah dalam masyarakat.

Salah satu tujuan penting pembelajaran sains adalah lahirnya individu-individu yang selalu responsif terhadap perkembangan ilmu pengetahuan dan teknologi, sekaligus peka terhadap isu-isu sosial yang timbul sebagai dampak dari perkembangan tersebut. Pendekatan STM dalam pembelajaran tentu dapat mengakomodir tujuan penting ini, karena dalam pendekatan STM (science technology and society approach) ini, peserta didik juga diajarkan untuk memperhatikan masalah-masalah yang kemudian muncul sebagai dampak lain dari penggunaan teknologiteknologi baru dalam kehidupan bermasyarakat. Dampak dari perkembangan sains dan teknologi di sini bukan hanya artian dampak negatif, tetapi juga dampak positifnya. Perlu dicatat bahwa sains dan teknologi serta masyarakat (society) mempunyai hubungan timbal balik dan saling mempengaruhi. Dengan memahami hakikat 
sains, teknologi dan perkembangannya serta dampaknya bagi masyarakat, maka peserta didik akan menjadi individu yang pada saatnya nanti terjun ke masyarakat dapat mengambil keputusan-keputusan/kebijakankebijakan yang tepat dalam kehidupannya sehari-hari. Selain itu, sudah barang tentu konsep-konsep dan prosesproses sains yang dipelajarinya di bangku sekolah bersesuaian dengan konsep-konsep dan proses-proses sains yang ditemuinya dalam kehidupan sehari-hari.

Pendekatan STM adalah suatu strategi pembelajaran yang menangkat isu-isu yang ditemui peserta didik di masyarakat ke dalam pembelajaran dan mengaitkannya dengan konsep sains yang ada, topik yang dipelajari kemudian dihubungkan dengan isu-isu yang sedang berkembang di masyarakat dengan ini diharapkan pembelajaran akan lebih menarik minat peserta didik.

\section{b. Tujuan Pendekatan Sains Teknologi dan Masyarakat}

Berdasarkan pengertian STM sebagaimana diungkapkan di bagian sebelumnya, maka dapat diungkapkan bahwa yang menjadi tujuan pendekatan STM ini secara umum sebagaimana diungkapkan oleh Rusmansyah (2006: 3) adalah agar para peserta didik mempunyai bekal pengetahuan yang cukup sehingga ia mampu mengambil keputusan penting tentang masalahmasalah dalam masyarakat dan sekaligus dapat mengambil tindakan sehubungan dengan keputusan yang diambilnya. 
Menurut Penn state (2008) dan NC State University (2006) bahwa tujuan dari pada STM secara garis besar adalah:

1. Peserta didik mampu menghubungkan realitas sosial dengan topik pembelajaran di dalam kelas.

2. Peserta didik mampu menggunakan berbagai jalan/perspektif untuk mensikapi berbagai isu/situasi yang berkembang di masyarakat berdasarkan pandangan ilmiah.

3. Peserta didik mampu menjadikan dirinya sebagai warga masyarakat yang memiliki tanggung jawab sosial.

\section{c. Karakteristik Pendekatan Sains Teknologi dan \\ Masyarakat}

Karakteristik Pendekatan Sains Teknologi dan Masyarakat menurut Yager (1992: 5-6) terdiri dari beberapa domain, yaitu: domain konsep, proses, aplikasi, kreativitas, dan domain sikao. Kelima domain itu secara lengkap dapat dijelaskan sebagai berikut:

\section{Domain Konsep}

Domain konsep ini memfokuskan pada muatan dan tujuan-tujuan sains untuk mengelompokkan keadaan alam yang teramati dan menjelaskan hubunganubungan dari proses pembelajaran dengan melibatkan peserta didik. Domain konsep meliputi fakta-fakta, informnasi, hukum-hukum, prinsip-prinsip, penjelasan-penjelasan keberadaan sesuatum dan teori yang digunakan.

\section{Domain Proses}


Domain proses meliputi aspek-aspek yang berhubungan dengan bagaimana para saintis berpikir dan bekerja, misalnya melakukan observasi, eksplanasi, pengklasifikasian, pengorganisasian data, pengukuran, pem buatan grafik, pemahaman, berkomunikasi, penyimpulan, prediksi, perumusan, pengujian hipotesis, identifikasi, pengontrolan variabel, penginterpretasian data atau informasi, pembuatan instrumen, dan alat-alat sederhana, serta pemodelan.

\section{Domain Aplikasi}

Domain ini meliputi mengaplikasikan konsep-konsep dan keterampilan dalam memecahkan masalah seharihari, memahami prinsip-prinsip ilmiah dan prinsipprinsip teknologi yang terdapat dalam kehidupan sehari-hari atau sains.

\section{Domain Kreativitas}

Dalam domain kreativitas meliputi visualisasi, menghasilkan gambaran mental, menggabungkan objek-objek dan ide dalam cara-cara baru, memecahkan masalah dan teka-teki, memprediksi konsekwensi-konsekuensi yang mungkin, menyarankan alasan-alasan yang mungkin, mendesain alat atau mesin dan menghasilkan ide-ide yang tak biasa.

\section{Domain Sikap}

Dalam domain sikap meliputi sikap-sikap terhadap sains pada umumnya, seperti kelas sains, kegunaan belajar sains, dan untuk guru terbentuknya pengembangan sikap-sikap positif terhadap diri 
sendiri yaitu sikap yang dapat mengerjakan sesuatu, eksplorasi emosi manusia, dan lain sebagainya yang berhubungan dengan sikap.

\section{d. Ciri-ciri Pendekatan Sains Teknologi dan Masyarakat}

Adapun ciri-ciri pendekatan sains teknologi dan masyarakat apabila diterapkan ke dalam sebuah pembelajaran, maka kita akan dapat melihat hal-hal berikut:

1. Masalah yang diangkat sebagai bahan pembelajaran bersifat setempat, nyata (real life situation), penting (bermakna) dan berdampak pada peserta didik

2. Saat kegiatan pembelajaran dipergunakan sumber daya setempat (dapat berupa narasumber (orang), bendabenda, lingkungan fisik (biotik dan abiotik) atau lingkungan sosial (masyarakat/society) dalam upaya untuk memperoleh informasi-informasi agar bisa dimanfaatkan untuk memecahkan masalah yang telah diangkat sebagai bahan pembelajaran

3. Pendekatan sains teknologi dan masyarakat (STM) menuntuk semua peserta didik untuk ikut serta terlibat secara aktif untuk memperoleh informasi-informasi untuk memecahkan masalah yang diangkat dalam kegiatan pembelajaran yang bersumber dari situasi nyata dalam kehidupan sehari-hari.

4. Pada umumnya penerapan science technology and society approach (pendekatan sains teknologi dan masyarakat) ini membutuhkan alokasi yang lebih banyak dibanding pendekatan tradisional. Untuk itu seringkali dibutuhkan 
perpanjangan waktu belajar peserta didik saat di sekolah maupun di luar jam belajar sekolah (di rumah)

5. Agar masalah yang diangkat dalam pembelajaran mempunyai makna yang mendalam bagi peserta didik maka masalah difokuskan pada dampak-dampak sains dan teknologi bagi peserta didik itu sendiri

6. Materi pembelajaran yang dibelajarkan kepada peserta didik saat menerapkan pendekatan STM (sains teknologi dan masyarakat) ini meliputi produk-produk (fenomena alam, gejala alam, konsep, prinsip, fakta, teori dan hukumhukum dalam sains) dan proses-proses sains (metode ilmiah pemecahan masalah sains)

7. Pembelajaran yang juga menekankan materi pembelajaran berupa proses sains (tidak sekedar produk) akhirnya akan memberikan peserta didik keterampilan sains yang mantap yang nantinya dapat mereka gunakan untuk memecahkan masalah dalam kehidupan sehari-hari yang berkaitan dengan sains dan teknologi dalam hubungannya dengan masyarakat

8. Penerapan pendekatan STM memberikan kesempatan kepada peserta didik untuk mulai memiliki kesadaran diri akan kemungkinan karier yang akan mereka miliki di masa mendatang yang tentu saja berkaitan dengan sains dan teknologi serta masyarakat

9. Saat guru menggunakan penerapan sains teknologi dan masyarakat dalam sebuah pembelajaran dan mengangkat isu-isu atau masalah dalam kehidupan nyata mereka sehari-hari, maka peserta didik mendapatkan sebuah kesempatan untuk berperan sebagai seorang warga masyarakat (warga negara) di mana mereka akan belajar memecahkan maslah-masalah tersebut 
10.Pada sebuah pembelajaran dengan penerapan sains teknologi dan masyarakat, peserta didik-peserta didik saat kegiatan belajar mengajar dilangsungkan belajar mencermati apa dan bagaimana dampak sains dan teknologi di masa depan.

11.Adanya kebebasan atau otonomi dalam proses belajar, sehingga mereka benar-benar membangun sendiri pengetahuan dan pemahamannya tentang sains, teknologi, dan masyarakat

\section{e. Penerapan Pendekatan Sains Teknologi dan Masyarakat}

Pendidikan IPS sebagai suatu mata pelajaran utama bagi peserta didik di sekolah, harus seanantiasa tanggap dan memnahi diri agar dapat mengikuti perkembangan jaman dan terutama ilmu pengetahuan (sains) dan teknologi yang ada dan berkembang di masyarakat. Proses pembelajaran dengan menggunakan pendekatan STM ini ditujukan untuk melatih dan membelajarkan agar konsep yang diterima oleh peserta didik dapat diterapkan oleh peserta didik dalam mengatasi masalah yang dihadapinya dalam kehidupan masyarakat.

Menurut National Science Teacher Association (NSTA) (1990:2) dalam pendekatan STM ada beberapa prinsip yang harus dimunculkan, antara lain:

1. Peserta didik melakukan identifikasi terhadap persoalan dan dalampak yang ditimbulkan dari persoalan tersebut muncuk di sekitar lingkungannya; 
2. Menggunakan sumber daya lokal untuk mencari informasi yang dapat digunakan dalam penyelesaian persoalan yang telah berhasil diidentifikasi;

3. Memfokuskan pembelajaran pada akibat yang ditimbulkan oleh sains dan teknologi bagi peserta didik;

4. Pandangan bahwa pemahaman terhadap konten sains lebih berharga daripada sekedar mampu mengerjakan soal;

5. Adanya penekanan pada keterampilan proses yang dapat digunakan peserta didik untuk menyelesaikan soal sendiri;

6. Adanya penekanan pada kesadaran berkarir, terutama karir yang berhubungan dengan saintek; dan

7. Memberikan kesempatan kepada peserta didik untuk memperoleh pengalaman tentang aturan hidup bermasyarakat yang dapat digunakan untuk menyelesaikan persoalah yang telah diidentifikasi.

Berikut adalah beberapa tahapan dari pendekatan STM:

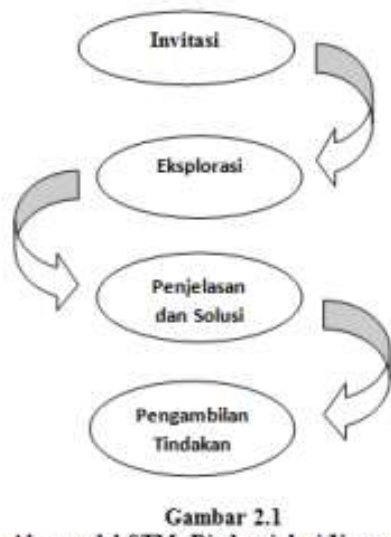


Dari gambar tersebut dapat dijelaskan sebagai berikut:

1. Tahap invitasi, peserta didik didorong agar mengemukakan pengetahuan awalnya tentang konsep yang dibahas.

2. Tahap eksplorasi, peserta didik diberi kesempatan untuk menyelidiki dan menemukan konsep melalui pengumpulan, pengorganisasian penginterpretasian data dalam suatu kegiatan yang dirancang guru.

3. Tahap penjelasan dan solusi, saat peserta didik memberikan penjelasan-penjelasan solusi yang didasarkan pada hasil observasinya di tambah dengan penguatan guru, maka peserta didik dapat menyampaikan gagasan, membuat model, membuat rangkuman serta kesimpulan.

4. Tahap pengambilan tindakan, peserta didik dapat membuat keputusan, menggunakan pengetahuan dan keterampilan, berbagai informasi dan gagasan, mengajukan pertanyaan lanjutan, mengajukan saran baik bagi individu maupun masyarakat yang berhubungan dengan pemecahan masalah.

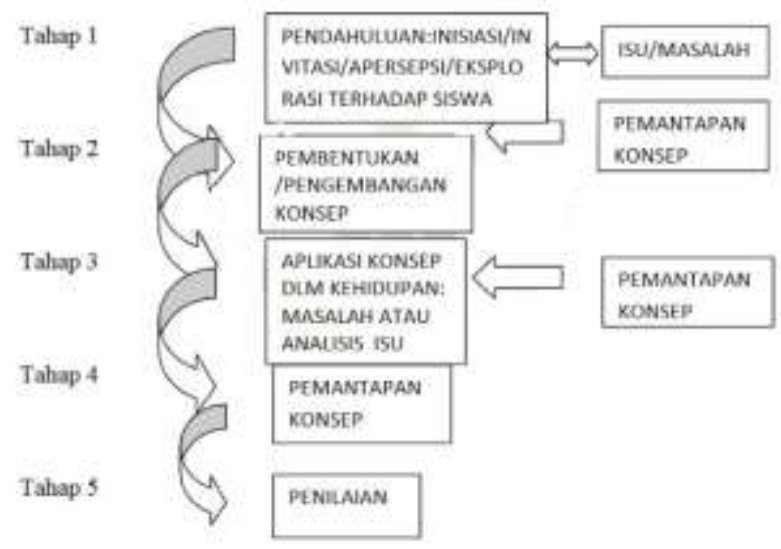

Gambar 6.2 Tahapan Pendekatan STM

Sumber: Poedjiadi (2007:126) 
Berikut adalah referensi lain terkait langkah-langkah pendekatan STM:

\section{Tahap Pendahuluan/inisiasi}

Dikemukakan isu/masalah yang ada di masyarakat yang dapat digali peserta didik, tetapi apabila guru tidak berhasil memperoleh tanggapan dari peserta didik, dapat saja dikemukakan oleh guru sendiri. Isu yang diangkat merupakan pernyataan yang mengandung pro dan kontra. Hal ini mengharuskan peserta didik berpikir untuk menganalisis isu tersebut. Apabila masalah berasal dari guru, peserta didik juga harus tetap berpikir tentang penyelesaian masalah yang direncanakan.

\section{Tahap pembentukan dan pengembangan konsep}

Dapat dilakukan dengan berbagai pendekatan dan metode, misalnya pendekatan keterampilan proses, pendekatan kecakapan hidup, eksperimen di laboratorium, diskusi kelompok, dll. Pada akhir pembentukan konsep diharapkan peserta didik telah dapat memahami apakah analisis tehadap isu/masalah yang dikemukakan di awal pelajaran telah menggunakan konsep-konsep yang diikuti oleh para ilmuwan.

\section{Tahap aplikasi konsep dalam kehidupan}

Berbekal pemahaman konsep yang benar, peserta didik melakukan analisis isu/masalah yang disebut aplikasi konsep. Adapun konsep yang telah dipahami peserta didik dapat diaplikasikan dalam kehidupan mereka sendiri.

\section{Tahap pemantapan konsep}

Guru meluruskan kalau ada miskonsepsi selama kegiatan belajar mengajar berlangsung. Apabla selama proses pembentukan konsep tidak tampak adanya miskonsepsi 
yang terjadi pada peserta didik, maka guru tetap perlu melakukan pemantapan konsep.

\section{Tahap evaluasi}

Guru memberi tes dan peserta didik diminta menjawab soal tes yang diberikan. Dari jawaban tes tersebut guru dapat menilai dan mengetahui tingkat keberhasilan pembelajaran dengan model STM.

\section{SIMPULAN}

1. Pendekatan STM adalah suatu strategi pembelajaran uang mengangkat isu-isu uang ditemui peserta didik di masyarakat ke dalam pembelajaran dan mengaitkannya dengan konsep sains yang ada, topik yang dipelajari kemudian dihubungkan dengan isu-isu yang sedang berkembang di masyarakat dengan ini diharapkan pembelajaran akan lebih menarik minat peserta didik.

2. Pendidikan IPS sebagai suatu mata pelajaran utama bagi peserta didik di sekolah, harus senantiasa tanggap dan membenahi diri agar dapat mengikuti perkembangan jaman dan terutama ilmu pengetahuan (sains) dan teknologi yang ada dan berkembang di masyarakat.

3. Langkah-langkah dalam pendekatan STM, antara lain: invitasi, eksplorasi, pengajuan eksplanasi dan solusi, serta tindak lanjut. 


\section{KERJAKAN AKU!}

Pendekatan STM sangat layak bahkan disarankan untuk diterapkan pada generasi alpha. Mengapa demikian? Jelaskan!

Buatlah rancangan sederhana pembelajaran SD dengan menerapkan pendekatan STM, tentu saja dengan memilih materi ajar yang sesuai! 


\section{DAFTARRUJUKAN}

Karli, H dan Yuliariatiningsih, M.S. (2002). Implementasi Kurikulum Berbasis Kompetensi. Bandung: Bina Medika Informasi

Poedjiadi, A. (1995). Efektivitas Pendekatan Sains Teknologi Masyarakat dalam Meningkatkan Literasi Sains dan Teknologi Peserta Didik di Sekolah Lanjutan Tingkat Pertama. Tesis: IKIP Bandung (tidak diterbitkan).

Rusmansyah dan Irhasyuarna. (2001). Implementasi Pendekatan

Sains Teknologi Masyarakat (STM) dalam Pembelajaran Kimia di SMU Negeri 1 Kota Banjarmasin.

Http://www.depdiknas.go.id/ jurnal/40/Implementasi\%20Pe ndekatan \%20Sains-Teknologi-Masyarakat.html (diakses tanggal 23 Desember 2010).

State, Penn. (2008). Macam-macam Pendekatan. http://idahariyanti.student.fkip.ums.ac.id/files/2009.../SBMTGL-7.docx. (26 Oktober 2010)

Yager, R.E. (1992). The Status of Science Technology Society Reform Efforts Around The World. ICASE Year Book: Pensylvania Yager 


\section{BAB VII}

\section{PEMANFAATAN MEDIA DALAM PEMBELAJARAN IPS}

\section{TUJUAN PEMBELAJARAN}

- Mahasiswa mampu memahami pengertian media pembelajaran

- Mahasiswa mampu memahami fungsi dan kegunaan media pembelajaran

- Mahasiswa mampu mengidentifikasi karakteristik dan jenis0jenis media pembelajaran

- Mahasiswa mampu menyusun media pembelajaran IPS SD

\section{a. Pengertian Media Pembelajaran}

Media pembelajaran adalah suatu alat yang dapat membantu seseorang dalam menyampaikan tujuan dan materi pembelajaran yang dapat merangsang kemampuan kognitif, perasaan, dan minat peserta didik dalam proses pembelajaran. Media pembelajaran dapat berupa apapun asal membantu guru dalam menyampaikan materi pembelajaran.

Pengertian lainnya, media pembelajaran adalah segala alat, segala sumber daya, atau bahan yang digunakan dalam proses menyampaikan segala informasi guru kepada peserta didik. Media dapat berbentuk fisik atau non fisik.

Komunikasi yang efektif tergantung pada partisipasi si penerima. Orang akan bereaksi dengan jawaban, pertanyaan, atau tindakan. Dengan bantuan sistem saraf pesan itu dapat diterima dan dimengerti. Akhirnya si penerima mengirim kembali pesan yang telah diolah sebagai feedback. Dari fieedback ini si pengirim dapat mengetahui apakah komunikasi berlangsung efektif atau tidak. 
Agar proses komunikasi ini berjalan dengan lancar, maka digunakanlah media pembelajaran. Rumampak (1988: 5) mengartikan media sebagai setiap bentuk peralatan yang biasanya dipakai untuk memindahkan informasi antara orangorang. Adapun Rohani (1977: 3) menjelaskan media sebagai sesuatu yang dapat diindera yang berfungsi sebagai perantara atau sarana dalam proses belajar mengajar.

Dalam proses belajar mengajar, media yang digunakan untuk memperlancar komunikasi tersebut dinamakan media pembelajaran. Latuheru (1988: 13) menjelaskan sesuatu dapat diakatakan sebagai media pembelajaran apabila mereka (media tersebut) digunakan untuk menyalurkan atau menyampaikan pesan dengan tujuan-tujuan pendidikan dan pembelajaran. Menurut H. Malik (1994: 11), pengertian media pembelajaran adalah segala sesuatu yang dapat digunakan untuk menyalurkan pesan (bahan pembelajaran), sehingga dapat merangsang perhatian, minat, pikiran, dan perasaan.

Dengan demikian, jelaslah bahwa media pembelajaran adalah alat bantu yang digunakan dalam proses pembelajaran yang dimaksudkan untuk memudahkan, memperlancar komunikasi antara guru dan peserta didik sehingga proses pembelajaran berlangsung efektif dan berhasil dengan baik. Media pembelajaran menempati posisi yang cukup penting sebagai salah satu komponen dalam sistem pembelajaran. Tanpa media, komunikasi tidak akan terjadi dan proses pembelajaran sebagai proses komunikasi juga tidak akan berlangsung secara optimal. Seringkali ditemukan berbagai hambatan dalam proses pembelajaran dikarenakan kurang tepatnya atau bahkan tidak digunakannya media dalam pembelajaran. 


\section{b. Fungsi dan Kegunaan Media Pembelajaran}

Berikut adalah beberapa fungsi media pembelajaran secara umum:

\section{Menarik Perhatian Peserta didik}

Terkadang peserta didik kurang tertarik atau antusias terhadap suatu pelajaran dikarenakan materi pelajaran yang sulit dan susah dicerna. Dengan media pembelajaran, suasana kelas akan lebih fresh dan peserta didik dapat lebih berkonsentrasi, terlebih ketika media pembelajaran yang digunakan bersifat unik dan menarik.

\section{Memperjelas Penyampaian Pesan}

Dalam pelajaran, terkadang ada hal-hal berkonsep abstrak yang sulit bila dijelaskan secara lisan. Misalnya bagian-bagian tubuh manusia. Dengan media pembelajaran, seperti misalnya video, gambar ataupun kerangka manusia tiruan. Peserta didik akan lebih jelas memahami apa yang dijelaskan oleh guru di kelas.

3. Mengatasi Keterbatasan Ruang, Waktu dan Biaya

Ketika menjelaskan tentang misalnya hewan-hewan karnivora. Tidak mungkin rasanya kita membawa harimau, singa atau buaya kedalam kelas.

Dengan media pembelajaran seperti gambar, peserta didik mengerti apa yang dimaksudkan guru walaupun belum melihat bentuk objek secara langsung.

\section{Menghindari Kesalahan Tafsir}

Ketika pembelajaran secara langsung dan guru menyampaikan informasi secara verbal, ada kemungkinan salah tangkap oleh murid bahkan antar murid. Untuk 
meminimalisir salah tafsir, dengan menggunakan media pembelajaran diharapkan dapat menyampaikan informasi dengan baik.

\section{Mengakomodasi Perbedaan Tipe Gaya Belajar Peserta} didik

Manusia dibekali kemampuan berbeda-beda, termasuk dalam hal gaya belajar. Dalam sebuah teori, setidaknya ada tiga tipe gaya belajar, yakni visual, auditori, dan kinestetik.

Diharapkan guru dapat memadukan beberapa media pembelajaran dalam bentuk yang bervariasi dan mampu merapkan hampir semua jenis media pembelajaran (audio, audio visual, gambar, atau teks). Hal ini akan berdampak bagi peserta didik yang lemah dalam menangkap informasi secara lisan karena telah disampaikan dengan media pembelajaran yang sesuai dengan karakteristik peserta didik tersebut.

\section{Untuk Mencapai Tujuan Pembelajaran Secara Efektif}

Dengan media pembelajaran, proses belajar mengajar dikelas diharapkan sukses sesuai dengan tujuantujuan yang ingin dicapai oleh tenaga pendidik di kelas.

Implementasi media pembelajaran tentu saja memberikan pengaruh yang besar terhadap proses pembelajaran. Tentu saja banyak keuntungan yang dapat dirasakan bagi guru dan peserta didik. Contohnya: peserta didik mengalami kesulitan dalam menangkap informasi dan setelah mengamati melalui media pembelajaran, mereka dapat langsung menangkap maksud dari materi ajar. Prinsipnya, media pembelajaran adalah untuk 
mendukung serta membantu guru dalam menyampaikan informasi/materi supaya peserta didik lebih mudah. Tentu saja akan membutuhkan waktu dalam pembuatannya, namun dampaknya akan terasa luar biasa setelahnya.

Bukti lain adalah, minat peserta didik yang meningkat setelah diimplementasikan media pembelajaran. Ketika minat belajar peserta didik tinggi, maka pencapaian tujuan dan hasil belajar akan dapat dicapai dengan mudah dan cepat.

Hal ini membuat media pembelajaran mendapatkan nilai tambah. Mengapa? Karena proses belajar mengajar konvensional akan berubah ketika media pembelajaran dilibatkan didalamnya. Tentu saja, ada beberapa syarat yang harus dapat dipenuhi dalam pembuatan media pembelajaran sehingga peranan media tersebut tidak salah sasaran. Salah satunya adalah pemilihan jenis media yang disesuaikan dengan kebutuhan dan karateristik peserta didik/materi ajar.

Contoh lainnya, guru harus dapat menguasai cara menggunakan media pembelajaran dan dapat "menyalurkan" ke peserta didik sehingga mereka dapat juga merasakan keberadaan media pembelajaran

Salah satu media pembelajaran yang banyak digunakan adalah media pembelajaran berbasis visual. Media pembelajaran visual merupakan media pembelajaran yang mampu memperlihatkan materi pembelajaran dalam bentuk tampilan. Contoh media pembelajaran visual ini misalnya OHP, LCD Proyektor, Slide, dan sejenisnya. 
Media pembelajaran visual harus dipilih dan digunakan dengan seksama. Dengan pemilihan dan penggunaan yang baik dimaksudkan agar media pembelajaran visual dapat menjalankan fungsi-fungsi yang dimilikinya. Ada beberapa fungsi media pembelajaran, Levie dan Lentz dalam Arsyad (2013: 20) menyebutkan bahwa setidaknya terdapat empat fungsi yang dimiliki media pembelajaran:

\section{Fungsi Atensi.}

Media pembelajaran memiliki salah satu fungsi yaitu menarik minat peserta didik sehingga mereka dapat berkonsentrasi pada konten pelajaran yang berkaitan dengan makna visual yang ditunjukkan atau mengiringi teks materi pembelajaran. Sering dijumpai bahwa peserta didik tidak dapat fokus dalam kelas, namun keadaan berubah setelah mengimplementasikan media pembelajaran.

\section{Fungsi Afektif}

Ketika peserta didik melihat gambar atau tampilan visual dari media pembelajaran, diharapkan peserta didik dapat tergerak emosi/sikap nya sehingga mereka dapat menanggapi dengan perbuatan atau menganalisis fenomena yang ditampilan dalam media tersebut. Media pembelajaran tentu saja dapat merubah peserta didik menjadi lebih aktif lagi karena mereka mempraktekkan menggunakan media pembelajaran secara langsung.

\section{Fungsi Kognitif}

Penggunaan media visual yang berisi lambanglambang/simbol atau gambar-gambar yang relevan dengan materi akan memperlancar proses pembelajaran atau 
tujuan pembelajaran. Peserta didik akan lebih mudah memahami bahkan mengingat dalam jangka waktu yang lama.

\section{Fungsi Kompensatoris}

Media visual yang memberi konteks untuk memahami teks membantu peserta didik yang lemah dalam membaca untuk mengorganisasikan informasi dalam teks dan mengingatnya kembali. Media pembelajaran mampu mengakomodasi peserta didik yang lemah dan lambat menerima dan mempelajari pelajaran yang disajikan tanpa menggunakan media.

Fungsi-fungsi diatas sebenarnya tidak hanya dimiliki oleh media pembelajaran visual saja, namun juga berlaku pada media pembelajaran secara umum. Melihat cukup pentingnya fungsi-fungsi media pembelajaran, sepertinya saat ini proses belajar mengajar jauh lebih efektif jika media pembelajaran selalu dilibatkan dalam setiap pembelajaran. Tentu penentuan media pembelajaran harus memperhatikan hal-hal yang dapat mempengaruhi pembelajaran, serta juga memperhatikan prinsip-prinsip psikologis dalam pemilihan media pembelajaran.

Media pembelajaran visual, tentu saja mampu menampilkan tampilan nyata dari fenomena-fenomena atau kejadian nyata sehingga peserta didik mampu melihatnya secara langsung dan dapat meminimalisisr salah tafsir. Peserta didik tidak perlu membayangkan bagaimana serangkaian peristiwa (contoh peristiwa G30S $\mathrm{PKI}$ ) yang tentu saja guru akan mengalami kesulitan dalam menyampaikan perisitiwa tersebut. Hal ini tentu saja menjadi nilai lebih dari penggunaan media pembelajaran visual, asal dibuat dan diterapkan dengan baik. 


\section{c. Karakteristik Media Pembelajaran}

Media pembelajaran memiliki karakteristikkarakteristik yang berbeda antara jenis media yang satu dengan yang lainnya. Karakteristik tersebut dikelompokan disesuaikan dengan jenis dan juga penggunannya dalam proses pembelajaran, antara lain:

1. Media Visual adalah media yang hanya dapat dilihat dan didalamnya terdapat unsur unsur berupa bentuk, garis, tekstur, dan lainnya;

2. Media audio adalah media yang hanya dapat didengar. Isi pesan media ini diterima melalui indra pendengaran atau telinga; dan

3. Media audio visual adalah media kombinasi audio dan visual ia dapat menampilkan unsur verbal dan juga suara. Artinya ia dapat didengar dan dilihat secara bersamaan.

4. Multimedia adalah media yang merangsang semua indera dalam satu kegiatan pembelajaran.

\section{d. Jenis-jenis Media Pembelajaran}

\section{Media Berbasis Visual}

Visualisasi pesan, informasi, atau konsep yang ingin disampaikan kepada peserta didik dapat dikembangkan dalam berbagai bentuk, seperti foto, gambar/ilustrasi, sketsa/gambar garis, grafik, bagan, chart, dan gabungan dari dua bentuk atau lebih.

\section{Media Berbasis Audio visual}

Media audio visual merupakan bentuk media pembelajaran yang murah dan terjangkau. Sekali kita membeli tape dan peralatan yang murah dan 
terjangkau, maka hampir tidak perlu lagi biaya tambahan, karena tape dapat dihapus setelah digunakan dan pesan baru dapat diterima kembali. Disamping menarik dan memotivasi peserta didik untuk mempelajari materi lebih banyak.

\section{Media Berbasis Komputer}

Kemajuan media komputer memberikan beberapa kelebihan untuk legiatan produksi audiovisual. Pada tahun-tahun belakangan komputer mendapat perhatian besar karena kemampuannya yang dapat digunakan dalam bidang kegiatan pembelajaran. Ditambah dengan teknologi jaringan dan internet, komputer seakan menjadi primadona dalam kegiatan pembelajaran.

\section{Media Berbasis Edutainment}

Masih pemanfaatan media pembelajaran berbasis komputer ini, maka pemanfaatan media pembelajaran yang berbasis edutainment ini masih berbasis komputer dalam pendesainannya. Dengan penggunaan media pembelajaran berbasis edutainment dalam proses belajar mengajar dapat membangkitkan keinginan dan minat yang baru, dan rangsangan kegiatan belajar dan bahkan membawa pengaruhpengaruh psikologis terhadap peserta didik.

\section{Film Animasi}

Salah satu contoh dari media audio visual adalah film animasi. Secara umum, film animasi didefinisikan sebagai gambar-gambar yang muncul dan bergerak. Harrison \& Hummel (2010:20) mendefinisikan film 
animasi sebagai tampilan cepat dari urutan gambar statis yang menciptakan ilusi dan gerak.

\section{SIMPULAN}

1. Media Pembelajaran diartikan segala sesuatu yang dapat dipergunakan untuk merangsang pikiran, perasaan, perhatian dan kemampuan atau ketrampilan pebelajar sehingga dapat mendorong terjadinya proses belajar.

2. Fungsi utama media, adalah memotivasi minat dan tindakan, menyajikan informasi, dan memberi instruksi.

3. Jenis-jenis media pembelajaran, antara lain: media berbasis visual, media berbasis auido visual, media berbasis komputer, media berbasis edutainment, film animasi, dan lainnya

\section{KERJAKAN AKU!}

Media berbasis eduntainment sangat cocok bila diterapkan pada generasi alpha saat ini. Buatlah skema dan tuliskan langkah-langkah/prosedur membuat media berbasis edutainment sederhana dengan memperhatikan ketentuan membuat media! 


\section{DAFTARRUJUKAN}

Arsyad, A. (2013). Media Pembelajaran. Jakarta: Rajawali Press

Harrison, H.L. \& Hummel, L.L. (2010) Incorporating Animation Concepts and Principles in STEM Education. (Journal) USA: The Technology Teacher 


\section{BAB VIII \\ RANCANGAN PEMBELAJARAN}

\section{TUJUAAN PEMBELAJARAN}

- Mahasiswa mampu menyusun silabus pembelajaran

- Mahasiswa mampu merancang RPP

- Mahasiswa mampu merancang RPP 1 lembar

\section{a. Desain Pembelajaran}

Dalam mengajar, tentu saja guru harus menyiapkan perencanaan pembelajaran yang terdiri dari Silabus dan Rencana Pelaksanaan Pembelajaran (RPP) yang berpedoman pada Standar Isi. Kegiatan perencanaan pembelajaran meliputi kegiatan penyusunan RPP dan menyiapkan media pembelajaran, sumber belajar, perangkat evaluasi/penilaian pembelajaran, dan skenario pembelajaran. Dalam menyusun silabus dan RPP, perlu disesuaikan dengan pendekatan pembelajaran yang digunakan.

\section{Silabus}

Silabus dibuat sebagai acuan dalam menyusun RPP yang berisi kerangka pembelajaran untuk setiap materi ajar.

a) Identitas

mata

pelajaran

(khusus

SMP/MTs/SMPLB/Paket

B

dan

SMA/MA/SMALB/SMK/MAK/Paket C/ Paket C

Kejuruan); 
b) Identitas sekolah terdiri dari nama satuan pendidikan dan kelas;

c) Kompetensi inti, merupakan kompetensi minimal yang diusahakan untuk dicapai oleh peserta didik. Komptensi yang dimaksud mewakili aspek pengetahuan, sikap, dan keterampilan yang harus dipelajari dan dikuasai selama sekolah dalam suatu jenjang sekolah.

d) Kompetensi dasar, merupakan kemampuan turunan dari kompetensi inti dan lebih spesifik. Kompetensi dasar tetap mengacu pada kompetensi pengetahuan, sikap, dan keterampilan yang terkait muatan atau mata pelajaran;

e) Tema (khusus SD/MI/SDLB/Paket A);

f) Materi pokok, berisi prinsip, fakta, konsep, dan prosedutr yang relevan dengan bahan ajar dan karakteristik peserta didi yang ditulis dalam bentuk butir-butir. Materi pokok berisi rumusan indikator dari kompetensi dasar (mencapai kompetensi pengetahuan, sikap, dan keterampilan)

g) Pembelajaran, yaitu kegiatan yang dilakukan oleh pendidik dan peserta didik untuk mencapai kompetensi yang diharapkan;

h) Penilaian, merupakan proses mendapatkan informasi terkait hasil akhir capaian peserta didik dengan cara mengumpulkan dan mengolah data;

i)Alokasi waktu, diisi sesuai dengan jumlah jam pelajaran dalam struktur kurikulum untuk satu semester atau satu tahun; dan 
j) Sumber belajar, dapat berupa buku, media cetak dan elektronik, alam sekitar atau sumber belajar lain yang relevan.

Silabus harus dikembangkan oleh guru dengan mengacu standar nasional lainnya, seperti Standar Kompetensi Lulusan dan Standar Isi untuk satuan pendidikan dasar dan menengah dengan tetap memperhatikan karakteristik peserta didik sesuai pola pembelajaran di masing-masing tahun ajaran. Silabus akan dikembangkan pada RPP. Maka, silabus dan RPP memang harus berdampingan.

\section{Rencana Pelaksanaan Pembelajaran}

Rencana Pelaksanaan Pembelajaran (RPP) adalah kegiatan yang harus dilakukan oleh guru sebelum kegiatan mengajar dimulai. RPP berisi skenario pembelajaran untuk satu pertemuan atau lebih. RPP disusun mengacu pada silabus untuk mengarahkan peserta didik dalam usahanya mencapai Kompetensi Dasar (KD).

Dalam menyusun RPP, guru harus menyusun skenario sedemikian rupa secara lengkap sehingga pembelajaran dapat berjalan dengan baik dan mengikuti standar pembelajaran yang ada. Pembelajaran harus bersifat inspiratif, interaktif, memotivasi untuk berpartisipasi aktif dalam pembelajaran, menantang siswa supaya lebih berkembang, memberi kesempatan untuk mengembangkan kreativitas, minat, bakat, dan perembangan fisik dan psikologi peserta didik. RPP disusun secara sistematis dan terarah sehingga guru 
dapat membaca atau memahami dengan mudah apa yang sudah disusunnya. Adapun komponen RPP dibawah ini:

a) Identitas sekolah yaitu nama satuan pendidikan;

b) Identitas mata pelajaran atau tema/subtema;

c) Kelas/semester;

d) Materi pokok;

e) Alokasi waktu ditentukan sesuai dengan keperluan untuk pencapaian KD dan beban belajar dengan mempertimbangkan jumlah jam pelajaran yang tersedia dalam silabus dan KD yang harus dicapai;

f) Tujuan pembelajaran yang dirumuskan berdasarkan $\mathrm{KD}$, dengan menggunakan kata kerja operasional yang dapat diamati dan diukur, yang mencakup sikap, pengetahuan, dan keterampilan;

g) Kompetensi dasar dan indikator pencapaian kompetensi;

h) Materi pembelajaran, memuat fakta, konsep, prinsip, dan prosedur yang relevan, dan ditulis dalam bentuk butir-butir sesuai dengan rumusan indikator ketercapaian kompetensi;

i) Metode pembelajaran, digunakan oleh pendidik untuk mewujudkan suasana belajar dan proses pembelajaran agar peserta didik mencapai KD yang disesuaikan dengan karakteristik peserta didik dan KD yang akan dicapai;

j) Media pembelajaran, berupa alat bantu proses pembelajaran untuk menyampaikan materi pelajaran; 
k) Sumber belajar, dapat berupa buku, media cetak dan elektronik, alam sekitar, atau sumber belajar lain yang relevan;

1) Langkah-langkah pembelajaran dilakukan melalui tahapan pendahuluan, inti, dan penutup; dan

m)Penilaian hasil pembelajaran.

\section{Prinsip Penyusunan RPP}

Dalam menyusun RPP hendaknya memperhatikan prinsip-prinsip sebagai berikut:

a) Perbedaan individual peserta didik antara lain kemampuan awal, tingkat intelektual, bakat, potensi, minat, motivasi belajar, kemampuan sosial, emosi, gaya belajar, kebutuhan khusus, kecepatan belajar, latar belakang budaya, norma, nilai, dan/atau lingkungan peserta didik.

b) Partisipasi aktif peserta didik.

c) Berpusat pada peserta didik untuk mendorong semangat belajar, motivasi, minat, kreativitas, inisiatif, inspirasi, inovasi dan kemandirian.

d) Pengembangan budaya membaca dan menulis yang dirancang untuk mengembangkan kegemaran membaca, pemahaman beragam bacaan, dan berekspresi dalam berbagai bentuk tulisan.

e) Pemberian umpan balik dan tindak lanjut RPP memuat rancangan program pemberian umpan balik positif, penguatan, pengayaan, dan remedi.

f) Penekanan pada keterkaitan dan keterpaduan antara $\mathrm{KD}$, materi pembelajaran, kegiatan pembelajaran, indicator pencapaian kompetensi, penilaian, dan 
sumber belajar dalam satu keutuhan pengalaman belajar.

g) Mengakomodasi pembelajaran tematik-terpadu, keterpaduan lintas mata pelajaran, lintas aspek belajar, dan keragaman budaya.

h) Penerapan teknologi informasi dan komunikasi secara terintegrasi, sistematis, dan efektif sesuai dengan situasi dan kondisi.

\section{b. RPP 1 Halaman}

Mendikbud memberikan kemudahan kepada guru di seluruh Indonesia dengan menerbitkan edaran tentang penyederhanaan Rencana Pelaksanaan Pembelajaran (RPP).

Aturan tersebut tertuang dalam surat edaran nomor 14 tahun 2019. Diantaranya penyederhananaan RPP adalah memuat hanya tiga komponen inti saja, sedangkan untuk 10 komponen lainnya sebagai pendukung dan boleh digunakan.

Adapun ketiga komponen Inti tersebut terdiri dari tujuan pembelajaran, kegiatan pembelajaran dan penilaian atau asesmen. Berikut adalah gambar format RPP 1 lembar: 
Nama Satune Peablitikan

Yata Pelojatan/Tema

Xelas; Semester

Stateri Poknk

Alokasi Waktı

L. Tujuan Pentrelajaran

2. Lanchah-Langhah Reeiatnn Pembelajarmt

21. Alat bla Bahan

2.1.3. Alat

2.1.2. Bahan:

2.1. Pertanyzan

2.2. Serwa berlatih praktik /mengerjakan tugas halamas beku -

83. Skawa memoresentasikan hail krsjakelompok/individu

24. Menyimpalkan dan Penilaian Peinbelajatan

24.1. Keseimpulas Pembelojaran

242. Peniinian

Yonectabie

Kepala Sekolah

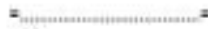

NIP
Saru Matalebiana 20. Keles.

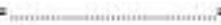

NII

"Catatan : Komponen Iainnya sebega peiengkap

Gambar 8.1. Format RPP 1 Lembar

Sumber: www.antapedia.com 


\section{SIMPULAN}

1. Rancangan Pembelajaran harus dibuat terlebih dahulu sebagai salah satu syarat diperbolehkannya mengajar. Rancangan tersebut terdiri dari: Silabus, RPP, dan Penilaian Pembelajaran

2. Tahun 2020, RPP dapat disederhanakan menjadi 1 lembar saja dengan tidak mengurangi komponen-komponen RPP yang semestinya.

\section{KERJAKAN AKU!}

Buatlah RPP 1 lembar dari RPP yang telah dibuat pada pertemuan sebelumnya! 


\section{DAFTARRUJUKAN}

Permendikbud. (2016). Standar Proses Pendidikan Dasar dan Menengah. Jakarta: BSNP

Kemdikbud. (2019). Penyederhanaan Rencana Pelaksanaan Pembelajaran. Jakarta: BSNP 


\section{DAFTAR PUSTAKA}

Arsyad, A. (2013). Media Pembelajaran. Jakarta: Rajawali Press

Budiningsih, A.C. (2005). Belajar dan Pembelajaran. Jakarta: Rineka Cipta

Dahlan, M.D. (1990). Model-model Mengajar. Bandung: CV Diponegoro

Fathurrohman, M. (2015). Model-model Pembelajaran Inovatif. Yogyakarta: Ar-Ruzz Media

Hamalik, O. (2001). Belajar Mengajar. Jakarta : Bumi Aksara Hamalik, O. (2003). Proses Belajar Mengajar. Jakarta: Sinar Grafika

Harrison, H.L. \& Hummel, L.L. (2010) Incorporating Animation Concepts and Principles in STEM Education. (Journal) USA: The Technology Teacher

Hasan, S.H. (1996). Pendidikan Ilmu Sosial. Jakarta: Depdikbud

Jarolimek, J. \& Forste, C.D. (1976) . Teaching and Learning in The Elementary School. London: Mc. Millan Pub.Co.Inc

Karli, H dan Yuliariatiningsih, M.S. (2002). Implementasi Kurikulum Berbasis Kompetensi. Bandung: Bina Medika Informasi 
Kemdikbud. (2019). Penyederhanaan Rencana Pelaksanaan Pembelajaran. Jakarta: BSNP

Kurinasih, I., \& Sani, B. (2014). Implementasi Kurikulum 2013, Konsep dan Penerapan. Surabaya: Kata Pena

Lie, A. (2002). Cooperative Learning; Mempraktekkan Cooperative Learning di Ruang-ruang Kelas. Jakarta: Grasindo

Mutakin, A. (1992). Pendidikan Ilmu Sosial. Bandung: Anggita Pustaka Mandiri.

Nurhadi. (2004). Pembelajaran Kontekstual (Contextual Teaching and Learning/CTL) dan Penerapannya Dalam $K B K$. Malang: Universitas Negeri Malang.

Permendikbud. (2016). Standar Proses Pendidikan Dasar dan Menengah. Jakarta: BSNP

Piaget, J. (1963). The Psychology of Intelligence. New York: Routledge

Poedjiadi, A. (1997). Memperkenalkan Pendidikan Sains Teknologi dan Masyarakat. Bandung: Program Pascasarjana IKIP Bandung

Poedjiadi, A. (1995). Efektivitas Pendekatan Sains Teknologi Masyarakat dalam Meningkatkan Literasi Sains dan Teknologi Peserta Didik di Sekolah Lanjutan Tingkat Pertama. Tesis: IKIP Bandung (tidak diterbitkan).

Roestiyah, N.K. (2008). Strategi Belajar Mengajar. Jakarta: Rineka Cipta 
Rusmansyah dan Irhasyuarna. (2001). Implementasi Pendekatan Sains Teknologi Masyarakat (STM) dalam Pembelajaran Kimia di SMU Negeri 1 Kota Banjarmasin.

Http://www.depdiknas.go.id/ jurnal/40/Implementasi\%20Pe ndekatan \%20Sains-Teknologi-Masyarakat.html (diakses tanggal 23 Desember 2010).

Sa'ud, U.S., \& Sutarsih. (2007). Pengembangan Profesi Guru. Bandung: Alfabeta.

Sanjaya, W. (2006). Strategi Pembelajaran Berbasis Standar Proses Pendidikan. Bandung: Alfabeta

Sanjaya, W. (2007). Kurikulum dan Pembelajaran. Jakarta: Kencana Prenada Media Group

Sapriya. (2002). Studi Sosial: Konsep dan Model Pembelajaran. Bandung: Buana Nusantara

Siroj, R.A. (2004). Pemerolehan Pengetahuan Menurut Pandangan Konstruktivistik. (online). Tersedia:

http://www.depdiknas.go.id/jurnal/43/rusdy-a-sirij.htm

Somantri, M.N. (2001). Menggagas Pembaharuan Pendidikan IPS. Bandung: UPI bekerja sama dengan PT Remaja Rosdakarya.

Suhada, I. (2016). Ilmu Sosial Dasar. Bandung: PT Remaja Rosdakarya

Surya, H.M. (2003). Kapita Selekta Pendidikan SD. Jakarta: UT

Susanto, A. (2014). Pengembangan Pembelajaran IPS di Sekolah Dasar. Jakarta: Prenadamedia Group 
State, Penn. (2008). Macam-macam Pendekatan. http://idahariyanti.student.fkip.ums.ac.id/files/2009.../SBMTGL-7.docx. (26 Oktober 2010)

Trianto. (2007). Model-model Pembelajaran Inovatif Berorientasi Kontekstualistik. Surabaya: Prestasi Pustaka

Trianto. (2010). Mengembangkan Model Pembelajaran Tematik. Jakarta: PT. Prestasi Pustakaraya.

Triwiyanto, T. (2015). Manajemen Kurikulum dan Pembelajaran. Jakarta: Bumi Aksara

Winataputra, U.S. (1997). Belajar dan Pembelajaran IPS. Jakarta: Proyek Strata DIII.

Yager, R.E. (1992). The Status of Science Technology Society Reform Efforts Around The World. ICASE Year Book: Pensylvania Yager 


\section{BIODATA PENULIS}

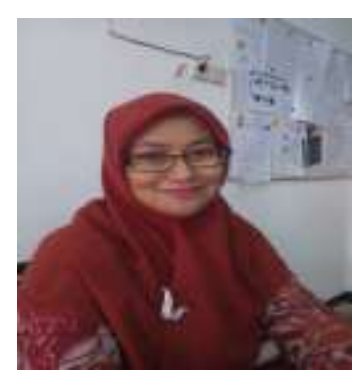

Vanda Rezania, lahir di Sidoarjo, Jawa Timur, tahun 1986. Pendidikan sarjana yang pernah ditempuh adalah Jurusan Psikologi Universitas Airlangga Surabaya dan lulus tahun 2008. Kemudian menempuh pendidikan pasca sarjana di Universitas Negeri Surabaya dengan mengambul program studi Pendidikan Dasar dan lulus pada tahun 2015. Pekerjaan yang pernah diemban adalah menjadi guru tetap yayasan SD Muhammadiyah 1 Krian dari tahun 2008-2010. Lalu, mengembangkan karirnya dengan menjadi dosen di Prodi PGSD FPIP Universitas Muhammadiyah Sidoarjo sejak 2010 hingga sekarang. Selama menjadi dosen, mata kuliah yang diampuh tidak jauh dari ilmu Psikologi, yaitu Psikologi Pendidikan dan Layanan Bimbingan di SD. Ilmu sosial juga diampuhnya, seperti Konsep Dasar IPS, Pendidikan IPS Kelas Awal dan Tinggi, serta Pengembangan Pembelajaran IPS di SD. Buku ajar yang telah dihasilkan adalah buku ajar Layanan Bimbingan di SD pada tahun 2018.

Rifki Afandi, merupakan dosen tetap prodi PGSD FPIP sejak tahun 2010 hingga sekarang. Dosen kelahiran tahun 1984 ini menempuh pendidikan S1 dengan Jurusan Pendidikan Ekonomi Universitas Negeri Malang dan pendidikan S2 dengan jurusan Pendidikan Dasar Universitas Negeri Surabaya. Saat ini penulis menempuh pendidikan doktoral di Universitas

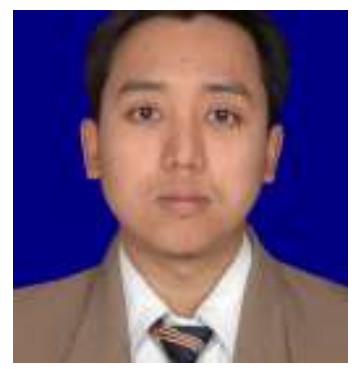
Negeri Yogyakarta. Beberapa artikel telah ditulisnya dan terpublish di jurnal-jurnal terakreditasi, salah satunya adalah Jurnal Inovasi Pembelajaran (JINoP) dan Jurnal Pemikiran dan Pengembangan Sekolah Dasar

(JP2SD). 
